\title{
توجه دولة قطر نحو اقتصـاد المعرفة
}

\author{
د. خالد الحلبى \\ مدرس بقسم المكتبات و الوثائق و المعلومات

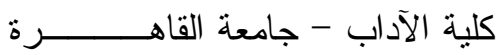

أولاُ تمهيل وإطار منهجحي:

تشكل إدارة المعرفة أحد التطور ات الفكرية المعاصرة التي اقترحت فــي بــادئ

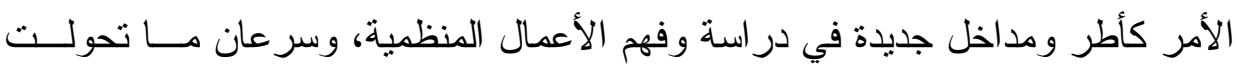
إلى ممارسة عملية, أكثر ملائمة للتغيير ات المتسار عة في عالم الأعمال، وقد تعساظٍ

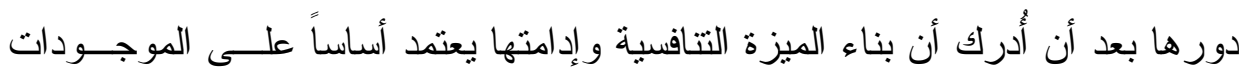

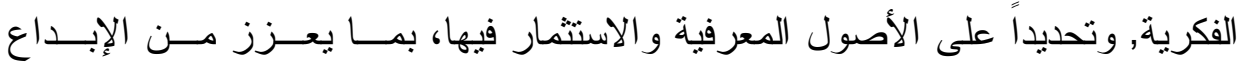

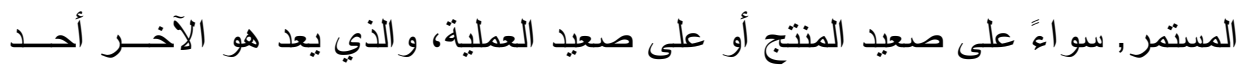
مقومات تعاظم تلاك الميزة لأطول فترة ممكنة. لكن هذه المعرفة بمفردها ليسست ذات نفع, و لابد من فعل للإدارة التي حولها يؤدي إلى تحقيق التتافس.

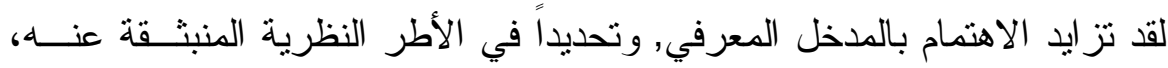
و التي تعالج موضو عات إدارية أو اقتصادية مع تتامي ظاهرة التغيير المتـسار ع فــي بيئة الأعمال, نتيجة لتضاؤل دور النظريات و المداخل التي كانت سائدة عـن وضـــع الحلول لمواجهة هذا التغيير , لاسيما بعد إدر الك أهمية المعرفة بوصفها موجوداً مهريــاً

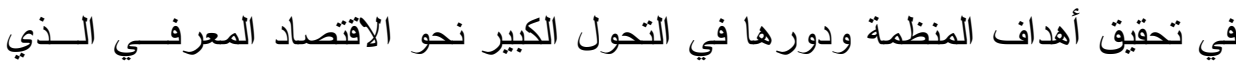
يركز على الاستثمار في الموجودات الفكرية و المعرفية غير الملموسة أكثر من تركيزه 
على الموجودات المادية الملموسة, وازداد هذا الدور أهمية مع سيادة مفهـوم عـصر المعرفة الذي من متطلباته ألا تكتفي المنظمات بتوفير المعلومات, بل يجب التفكير مع التع مدرد المعلومات.

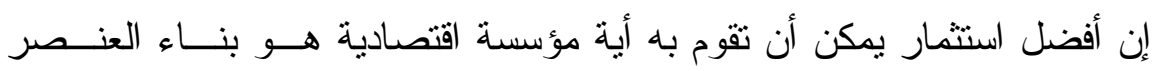
البشري العامل في تلك المؤسسة بحيث يتم أعداده ذهنيا ونفسيا بالقدر الذي يمكنه مــن

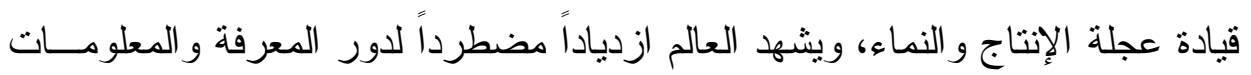
في الاقتصاد: فالمعرفة أصبحت محرك الإنتاج و النمو الاقتصادي كما أصــبح مبــــأ التركيز على المعلومات و التكنولوجيا كعامل من العو امل الأساسية في الاقتصـاد مــن

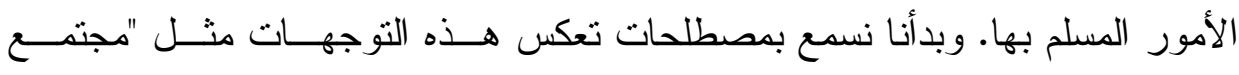
المعلومات "وثورة المعلومات" و " اقتصاد المعرفة" و "قتصاد التعليم" وغير ها.ويزداد استثمار الدول في المعرفة و المعلومات من خلال الصرف علــى التعلـيم و التــدريب و التطوير في القطاعين العام والخاص. فالاستثمار في المعلومات أصبح أحد عو امـلـل

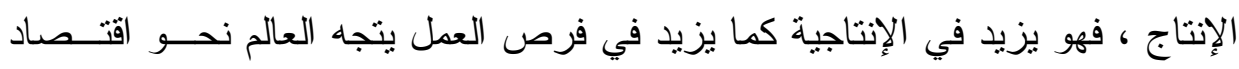

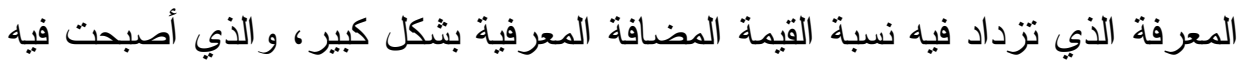
السلع المعرفية أو سلع المعلومات من السلع الهامة جداً، ونساعد تكنولوجيا المعلومات نئل و الاتصالات في نمو اقتصاد المعرفة .

\section{أهمية الدراسة :}

الاقتصـاد هو عماد الحياة، وهو من أهم العوامل التي تـسـاعد علـى اســتمر ارية

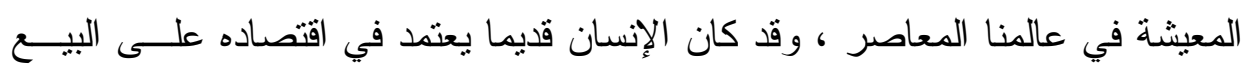

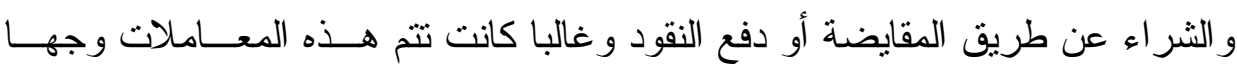
لوجه أو عن طريق الوسطاء في صفقات الأعمال الكبيرة . إن التحول الكبير من الاقتصاد التقليدي إلى اقتصاد المعرفة أحدث ثورة كبيرة في

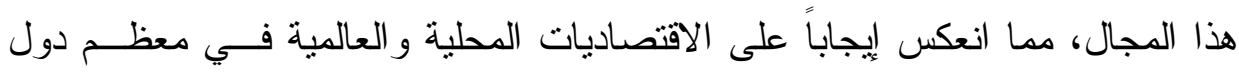
العالم التي استفادت من هذا التطور في زيادة الناتج المحلي لها، و إيجاد فرص وظيفية

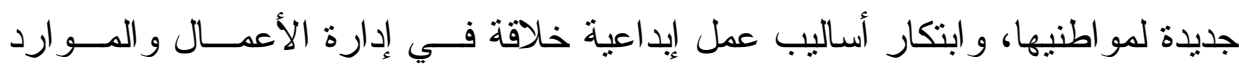


توجه خولة قهر نحو اقتهات المحرفة

البشرية و المالية و الإنتاجية. وهذا التحول الكبير قلب المفاهيم النظرية و العمليــة فــي عالم المال و الأعمال، بحيث أصبح الاقتصاد الرقمي و العمل به هو السائد في أعمــال القطاع الخاص العالمي ومؤسسات الأعمال و إدارتها وعلاقاتها مع قطاعات الأعمــال الأخرى على المستوى المحلي و العالمي، مما أنعكس إيجاباً على زيادة رؤوس أمو الها وتضاعف أرباحها، بفضل استخدام التطبيقات التقنية و المعلوماتية في هذا المجال فمـنـ

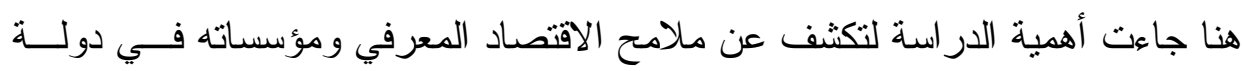
قطر كنموذج من دول الخليج العربية التي تتسار ع فيها خطى إقامة اقتصاد مبني على الى المعرفة.

\section{أهداف الدراسة :}

\section{يمكن تحديا أهداف الار اسة فيما يلي :}

1- التعريف بالاقتصاد المعرفي و عناصره وسماته الأساسية . r- التعرف على مكونات الاقتصاد المعرفي وملامحه ومقوماته.

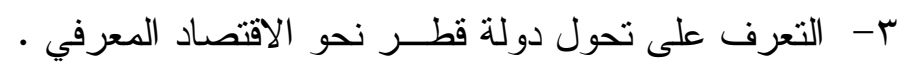
ع- - التعريف بملامح الاقتصاد المعرفي في قطر و أهم مؤسسات اقتصاد المعرفة.

\section{تساؤلات الدراسة}

في ضوء الأهداف التي تم تحديدها، أمكن صياغة مجموعة مــن التساؤلات

$$
\text { التي تحاول الدر اسة الإجابة عليها: }
$$

1- ما هو الاقتصاد المعرفي ؟ وما هي أهم عناصره ؟

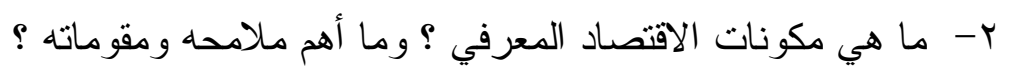

ب- ما أثر اقتصاد المعرفة على الأعمال ؟

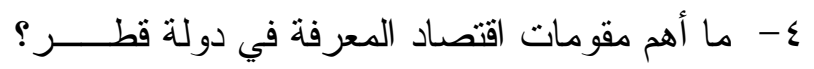

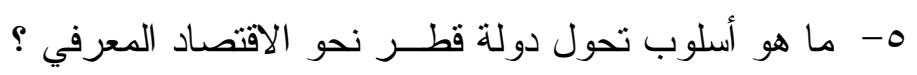


ح. خالو الحلبى

\section{منهج وحلدود الدراسة :}

الحدود الموضوعية:

التعريف بالاقتصاد المعرفي وتأثيره على سير الأعمال وتحول دولة قطر إلى الاقتصاد المعرفي ومظاهر ذلك.

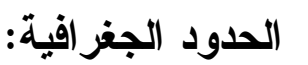

دولة قطر

\section{• الحدود الزمنية:}

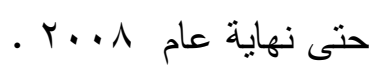

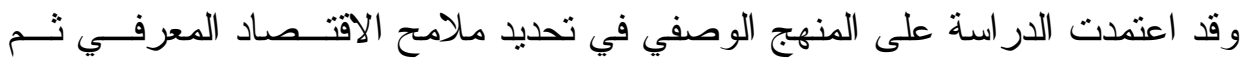
منهج در اسة الحالة للتعرف على التوجه القطري نحو مجتمع الاقتصاد المعرفي.

\section{مصطلحات اللدراسة :}

1- المعرفة : هي حصيلة الامتز اج الخفي بين المعلومة و الخبــرة و المــدركات الحسية والقدرة على الحكم. نتلقّى المعلومات ونخرجها بما تدركــه حو اســـنا. المعلومات وسيط لاكتساب المعرفة ضمن وسائل عديدة كالحـــس و التخمــين

$$
\text { و الممارسة الفعلية و الحكم بالسليقة. (') }
$$

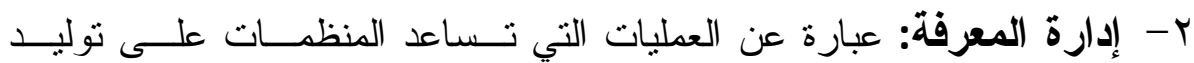
و الحصول على المعرفة، اختيار ها، تتظيمهأ، استخدامها، ونشر ها ، وتحويــلـ

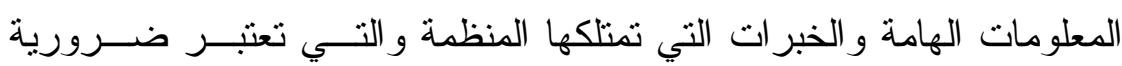

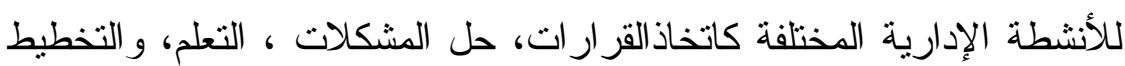

$$
\text { الإستر اتيجي. (r) }
$$

ب- الاقتصاد المعرفي: الاقتصاد الذي يدور حول الحــصول علــى المعرفــة، و المشـاركة فيها، و استخدامها، وتوظيفها، و ابتكار ها، بهــدف تحسـسين نو عيــة الحياة بمجالاتها كافة، من خلال الإفادة من خدمة معلوماتية ثرية، وتطبيقـات وتهات

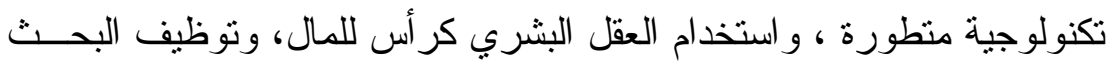
العلمي ، لإحداث مجمو عة من التغيير ات الإستر اتيجية فـي طبيعـــة المحـيط 
توجه خولة قهر نحو اقتهات المعرفة

الاقتصـادي وتتظيمه ليصبح أكثر استجابة و انسجاماً مــع تحــديات العولمـــة

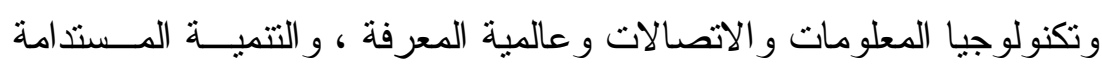

(r) بمفهومها الثمولي التكاملي

\section{ثانيا الإطار النظري للدراسة: مفهوم الاقتصاد المعرفي ا - تعريف الاقتصاد المعرفي:}

اقتصاد المعرفة هو فرع جديد من فروع العلوم الاقتصادية ظهر فــي الآونـــة

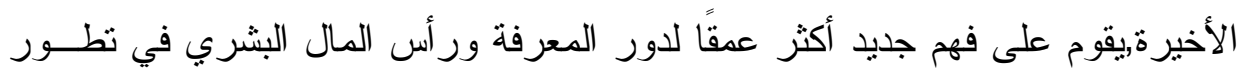
الاقتصاد وتقدم المجتمع.

إن مفهوم المعرفة ليس بالأمر الجديد بالطبع, فالمعرفة رافقت الإنسان منــــ أن تقتّحَ و عيه, وارتقت معه من مستوياتها البدائية, مر افقة لاتساع مداركه وتعمقها, حتـى لنى

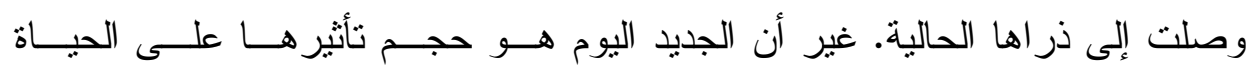

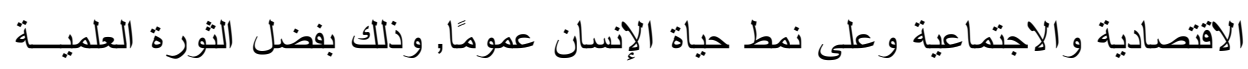
التكنولوجية. فقد شهر الربع الأخير من القرن العشرين أعظم تغيير في حياة البـشرية,

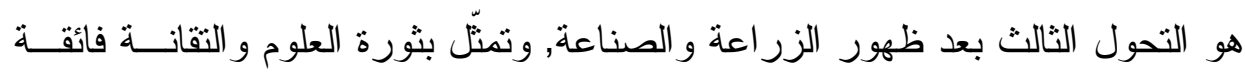
النطور في المجالات الإكترونية والنووية و الفيزيائية و البيولوجية و الفضائية.

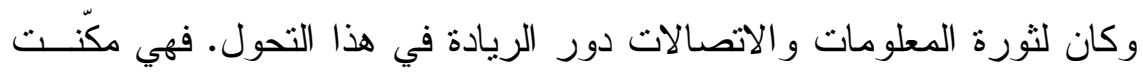
الإنسان من فرض سيطرته على الطبيعة إلى حد أصبح عامل التطور المعرفي أكتــر

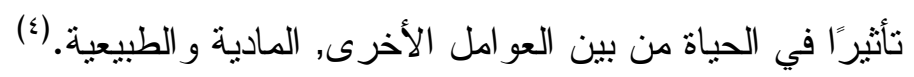
ومن خلال وجهة نظر عبد الرحمن الحاج يرى ان اقتصاد المعرفة هو الاقتصاد الذي تحقق فيه المعرفة الجزء الأعظم من القيمة المضافة وهذا يعني ان المعرفة تشكل مكوناً أساسيا في العملية الإنتاجية كما في التسويق وإن النمو يزداد

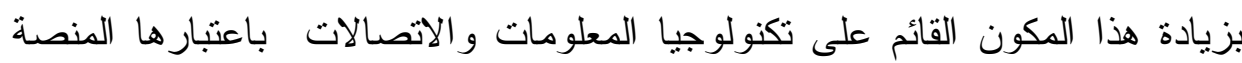
الأساسية التي يطلق منها.(ْ) بعبارة أخرى يمكن القول أن اقتصاد المعرفة هو الاقتصاد الذي يلعب فيه نشوء واستثمار المعرفة دوراً أساسيا في خلق الثروة فالثروة 
في الحقبة الصناعية تم إنشاؤها باستخدام الآلات و الطاقة و العديد من الناس يربطون اقتصاد المعرفة بالصناعات التكنولوجية مثل خدمات الاتصالات و الخدمات المالية حيث نجد في الاقتصاد المعرفي ان تقنية المعلومات ورأس المال الفكري هما القوة المحركة للاقتصاد هذا النوع من الاقتصاد سيجعل المهن اليوم و المستقبل مرتبطة thourpury بشكل معقد بتقنيات المعلومات والاتصالات بشكل مباشر ويقدر مركز centre

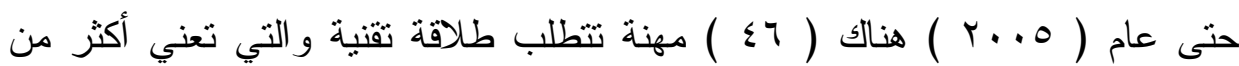
مجرد ثقافة تقنية انها تعني ان يتعامل الفرد مع التقنية بأريحية لا نقل عنها عند قراءة

$$
\text { صحيفة . مجزد }
$$

في حين كانت الأرض، و العمالة، ورأس المال هي العوامل الثلاثة الأساسية للإنتاج في الاقتصاد القديم، أصبحت الأصول المهمة في الاقتصاد الجديد هي المعرفة

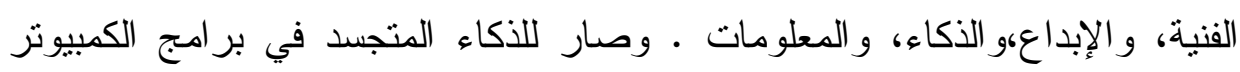
و التكنولوجيا عبر نطاق و اسع من المنتجات أهمية تفوق أهمية رأس المال، أو المو اد، وله أو العمالة. وتقدر الامم المتحدة أن اقتصادات المعرفة تستأثر الآن V ٪ من من الناتج

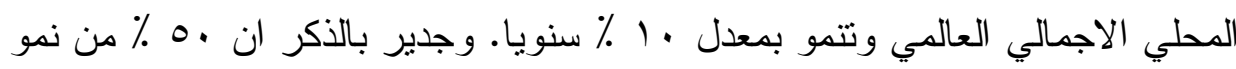

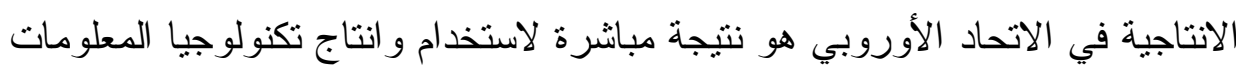
و الاتصالات.

knowledge society وقد استخدم مصطلح اقتصاد المعرفة و مجتمع المعرفة

The Age of في الفصل الثانى عشر مــن كتــاب and knowledge economy Peter F. Drucker \ Discontinuity للتأكيد على جو انب مختلفة لاقتصاد المعرفة منها مجتمــع المعلومسـات و الاقتـــاد،

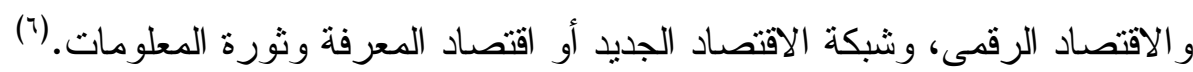
وبناء على ما تقدم فان اقتصاد المعرفة في الأساس بقصد به أن تكون المعرفة

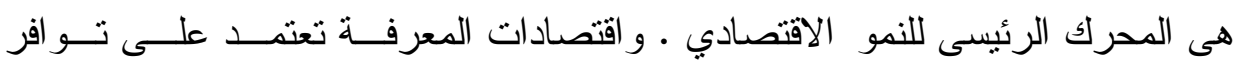

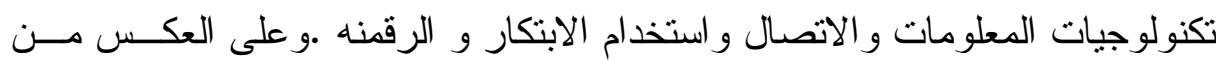


توجه خولة قهلر نحو اقتهات المحرفة

الاقتصاد المبني على الإنتاج، حيث تلعب المعرفة دورا أقل، وحيـــث يكـون النمـــو مدفو عا بعو امل الإنتاج الثقليدية، فإن الموارد البشرية المؤهلة وذات المهار ات العالية،

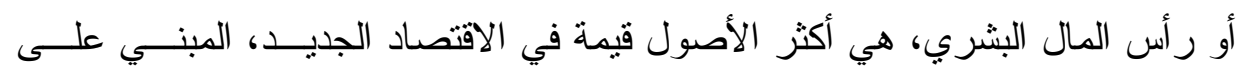
المعرفة.وفي الاقتصـاد المبني على المعرفة ترتفع المساهمة النسبية للصناعات المبنيـــة على المعرفة أو تمكينها، وتتمثل في الغالب في الصناعات ذات التكنولوجيا المتوسطة و الرفيعة، مثل الخدمات المالية وخدمات الأعمال.

\section{r - الاقتصاد المعرفي وتطوره من :}

منذ نشأة الخليقة على ظهر الأرض و الإنسان يسعى إلى المعرفة بشتى أثنكالها

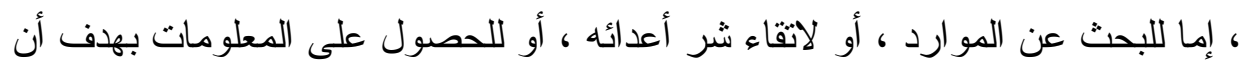

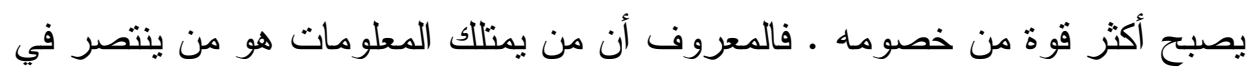
النهاية.

وقد حدثت الكثير من التغيرات خلال رحلة الإنسان في البحث عن المعرفة وتوظيفها ، للاستفادة منها ، و إذا ما وضعنا كل تلك التغير ات في إطار و احد، فسيتين لنا بوضوح أننا بصدد اختر اع شيء جديد على ظهر الأرض وأن هذا الثيء يتمنل وإنل تحديداً في نظام ثوري لإنتاج الثروة.

وقد تتبه علماء الاقتصاد إلى ذلك النظام في فترة مبكرة ترجع إلى عام بالى 197 وذلك عندما قام البروفيسور "فريتز ماتشلب" الأستاذ بجامعة "برينستون" بطبع كتاب بعنو ان "إنتاج وتوزيع المعرفة في الولايات المتحدة" والذي أظهر فيه أن الاقتصادات، بما فيها الاقتصاد الأميركي، غدت تعتمد بشكل متز ايد على المعرفة. أما الاقتصاديون التقليديون فقد استمروا في الاعتماد على أدوات القياس، و النماذج، والأفكار، العائدة

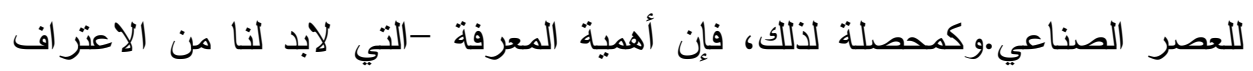
بأنها من الأثياء الصعبة القياس- كانت نتز ايد بشكل مطرد، في نفس الوقت الذي التي

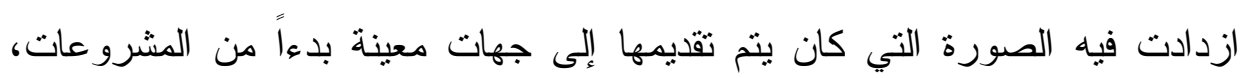
و الحكومات، و المؤسسات الدولية الرئيسية وحتى منظمة التجارة العالمية والأمم المتحدة، انفصالا عن الواقع حتى وصلت إلى نقطة أصبحت الفجوة بين الصورة 
و الواقع أكبر مما يمكن تجاهله.ومن بين الأسباب الرئيسية التي أدت إلى عجز الاقتصادات عن التكيف مع المتغيرات الاقتصادية، تللك الصعوبة المطلقة التي يو اجهها الاقتصاديون في التعريف الدقيق للمعرفة، و العمل المعرفي، وكيفية قياسهما، وكذلك

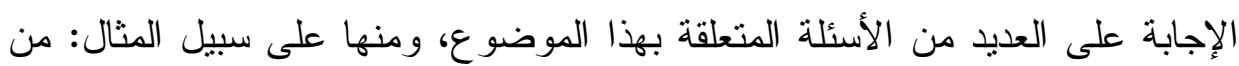
هم العاملون في مجال المعرفة؛هناك مشروع لتصنيف "فئات" الموظفين متداول على نطاق واسع، يقول إن المرء كي يكون من ضمن العاملين في حقل المعرفة، فإنه يجب

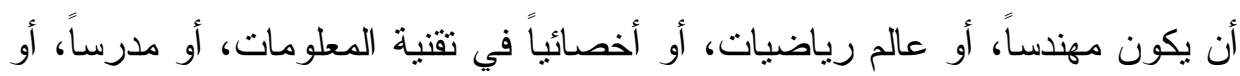

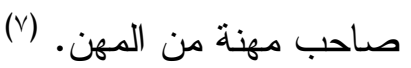
و اقتصاد المعرفة (الجديد كعلم بمقاييس نشوئه زمنياً) يحدد بمرحلنين تاريخيتين متفاوتتين بخصوصيتهما : الأولى : قديمة قدم التاريخ نتكون عملياً من جملة عناصر مختلفة تتتاسب مع تاريخيتها تتجسد حو املها المعرفية بالعادات و التقاليد و اللغة والتر اكم المعرفي في المجالات المختلفة البيئية و الجغر افية والتاريخية و المعمارية و الجمالية والاجتماعية و الاقتصادية و الصناعية و الطبية و غيرها من التز اكمات المعرفية غير المنتهية و المتوفرة حتى الآن و التي ما زالت تحكمنا بطابعها ونعيش في ظلها ضمن إطارها المعرفي التاريخي التز اكمي حاملة بين طياتها بعداً اقتصادياً يمكن استثماره وطنيا بحسن إدارة و إر ادة.

الثانية : حديثة تمتذ لعدة عقود مضت بدأ حديثاً وضعها في إطار علمي منذ ب797 97 يمثلها جملة من العناصر تتمثل في العلم و العلماء و الجامعات ومر اكز البحث المختلفة التي تحقق ما يسمى التراكم المعرفي و الذي يقود لإنتاجية وتائر ها عالية في قطاعات الإنتاج المعروفة ويمتاز هذا التر اكم المعرفي بأنه بدأ يصيغ شكلاً من أثنكال رأس المال غير الملموس( رأس المال المعنوي ) ذو القيمة المرتفعة جداً(^). والافتراض الذي بين أيدينا هو أن قوة العمل المعرفية هي حاصل جمع كل هؤلاء. وقد توصل هذا المشروع التصنيفي من خلال هذا المنظور إلى استتناج مؤداه أنه قد غدا بمقدورنا حساب نسبة مساهمة تلك الفئات في إنتاج الدخل القومي الإجمالي 
توجه خولة قهر نحو اقتهات المعرفة

و غيره من المتغير ات.ولكن الحقيقة هي أن هذا الاستتناج ساذج في أفضل الأحوال، ومضلل في أسوئها، لأنه يقلل بشكل جذري من قيمة التأثنر الذي وصل إليه العمل المعرفي في الاقتصاد الحقيقي، وكذلك من عدد العاملين الذين يقومون بإنتاج المعرفة.مع ذلك فإننا نجد أنه حتى في المجتمعات الأكثر تقدما، لا يز ال الدور الحقيقي

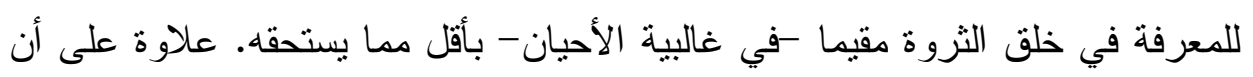
علماء الاقتصاد وخبر اءه، لاز الو ا حتى الآن غير قادرين - في معظم الأحيان أيضا -

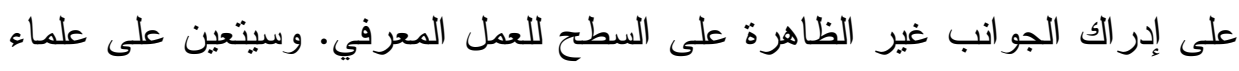
الاقتصاد من أجل التكيف مع الأهمية المتز ايدة للمعرفة، أن يقوموا بتقسيم تلك المعرفة إلى أنماط فرعية: فالمعرفة ليست واحدة، وليست لدى أنو اعها المختلفة قدرة منساوية على إنتاج الثروة. لذلك نقول إن علماء الاقتصاد حتى في الحالات التي يقومون فيها بتصنيف العديد من الوظائف على أنها تتدرج ضمن فئة الوظائف التي لا تحتاج سوى

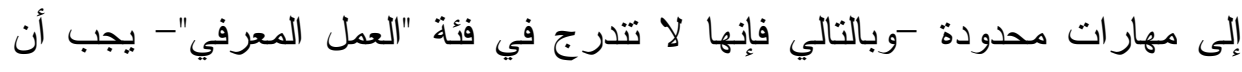
يعرفو أن تلك الوظائف تحتوي على مكون معرفي في حقيقة الأمر • يمكن فهر هذه

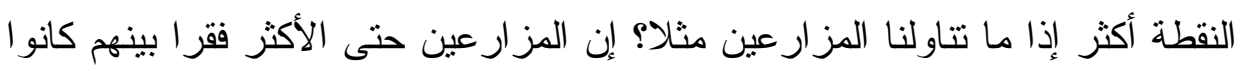
عبر التاريخ، في حاجة إلى الحصول على معرفة عن أنواع البذور و التربة و الجو . و اليوم نجد أنه في دولة مثل الولايات المتحدة، على سبيل المثال، تقوم المنظمات الزراعية التي تمثل مز ارعي الذرة و القطن وفول الصويا، بالتعاون مع "إدارة علوم

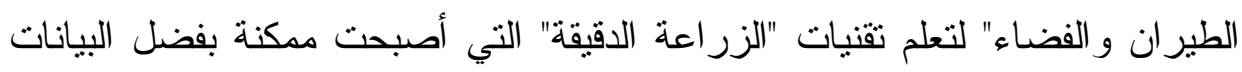
التي يتم الحصول عليها عن طريق الأقمار الاصطناعية، والطائرات التي تطير على اعلى

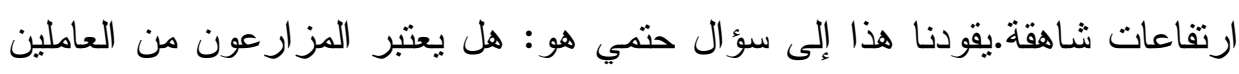
في مجال المعرفة؟ وإذا كانوا كذلك، فهل هم عمال معرفة متفرغون أم أنهم عمال معرفة يعملون لنصف الوقت فقط?على العموم فإن نطاق العمل المعرفي في الاقتصادات المتقدمة سيصبح أوسع نطاقاً مما هو عليه الآن.. وذللك إذا ما أقر علماء

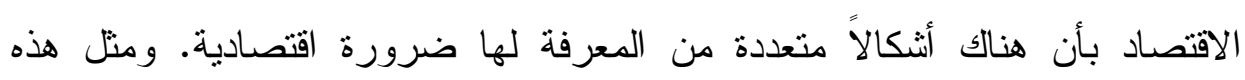

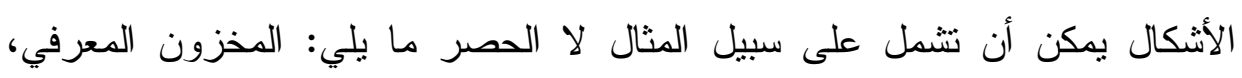


و البصيرة الثخصية، وموهبة القيادة، وغيرها من المهارات الاجتماعية و الثقافية

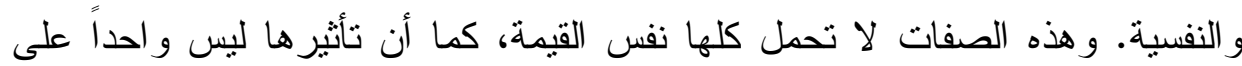
النتيجة الإجمالية التي تحققها الثركات و المؤسسات في صورة ربح أو خسارة، أو لون

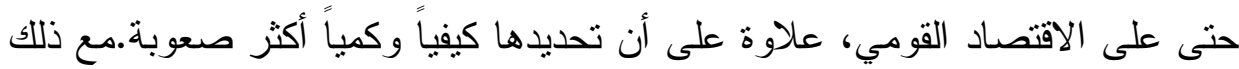
نجد أن هناك طريقة أخرى يتم بها تصنيف العمل المعرفي إلى فئات ومن بينها تحديد ما إذا كان العمل المر اد تصنيفه من النوع الذي يتم نوليده، أو تخزينه، أو تبادله، أو له تغييره. كما يمكن تصنيف العمل المعرفي أيضا وفقا لدرجة التجريد المطلوبة في الوظائف المختلفة بدءا من تسجيل البيانات ثم صعودا على سلم التجريد حتى الوصول

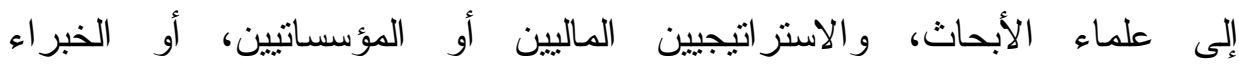
الاستثماريين.وفي الحقيقة أن "معرفتتا بالمعرفة" -إذا جاز التعبير - ضعيفة للغاية إلى درجة أننا جميعاً، وليس الاقتصاديين وحدهم، غير مستعدين لمواجهة ما بنتظرنا في

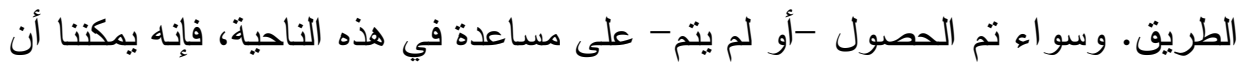
نقول إنه وإلى أن يحين الوقت الذي يصبح فيه الاقتصاديون قادرين على قياس هذه الأبعاد الخاصة بالعمل المعرفي، فإنهم سيستمرون في التقليل بشكل حاد ليس فقط من مقدار مساهمة العمل المعرفي في اقتصاد النقود، ولكن أيضاً من أهمية الدور الذي يلعبه العمل المعرفي بالفعل في اقتصاد الثروة الثوري، الذي تشرق شمسه الآن على

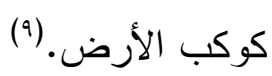

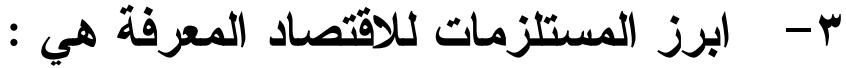

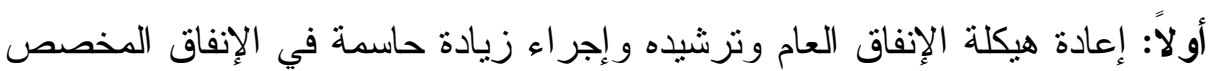

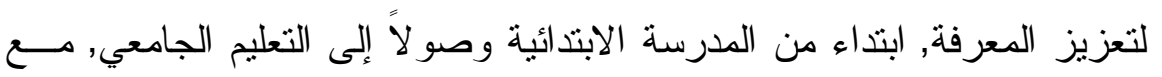
توجيه اهتمام مركز للبحث العلمي. وتجدر الإشارة هنا إلى أن إنفاق الولايــات

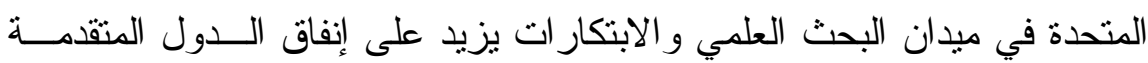
الأخرى مجتمعة, ما يساهم في جعل الاقتصاد الأمريكي الأكثر نطورًا ودينامية في العالم (بلغ إنفاق الدول الغربية في هــذا المجــال . بـ مليــار دولار عـــام

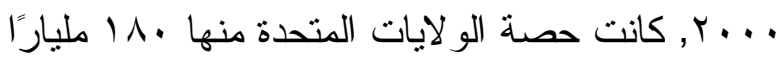


ثانيًا: وارتباطًا بما سبق, العمل على خلق وتطوير رأس المال البشري بنوعية عاليــة. و على الدولة خلق المناخ المناسب للمعرفة. فالمعرفة اليوم ليست (ترفًا فكريًّاً), بل أصبحت أهم عنصر من عناصر الإنتاج. ثالثًا: إدر الك المستثمرين و الثركات أهمية اقتصاد المعرفة. و الملاحظ أن الـشركات الـشات العالمية الكبري (العابرة للقوميات خصوصنًا) تساهم في تمويل جزء من تعلــيم

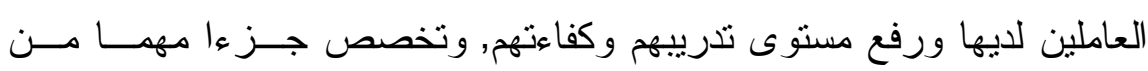

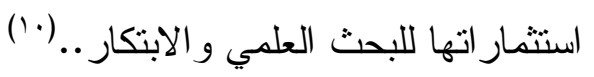
ع - عناصر الاقتصاد المعرفي : عنائ تتمنل عناصر الاقتصاد المعرفي فيما يأتي : - بنية تحتية مجتمعية داعمة. Wide connectivity - broadband الربط الو اسع ذو الحزمة العريضة الذي يسهل نقل المعلومات بشكل سريع و على نطاق واسع.

$$
\text { - مجتمع يسعى القدرة على الوصول اللى الإنترنت. }
$$
- عمال وصناع معرفة لديهم: معرفة، قدرة على التساؤل، و الربط. - منظومة بحث وتطوير فاعلة. (') ه - متطلبات مجتمع الاقتصاد المعرفي : 1 - تتمية القدرة على البحث و الاكتشاف والابتكار . r - تتمية القدرة على التعلم المستمر و اكتساب المعرفة وتوظيفها و إنتاجها وتبادلها r- تمكين الفرد من توظيف تكنولوجيا المعلومات و الاتصالات بفاعلية ع - تعزيز القدرة على إحداث التغيير و التطوير ه- تتمية القدر ات العقلية و الإبداعية دعما للتفوق و التميز

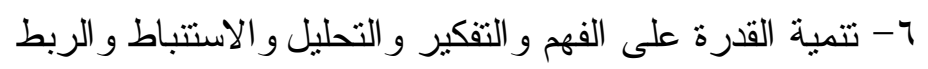

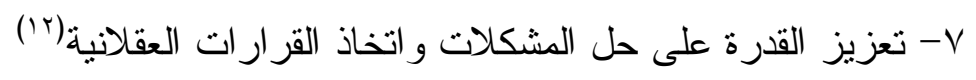




\section{خصائص وسمات الاقتصاد المعرفي :}

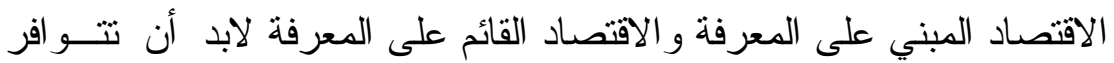

$$
\text { فيه عدد معين من الخصائص من أبرزها : }
$$

1 - الابتكار: نظام فعال من الروابط التجارية مع المؤسسات الأكاديمية غير ها مــن

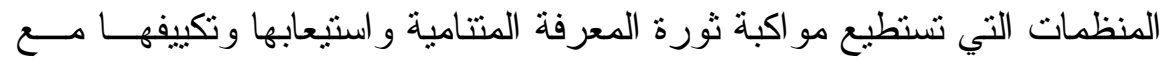

$$
\text { الاحتياجات المحلية }
$$

Y- التعليم أساسي للإنتاجية التنافسية الاقتصادية: يتعين على الحكومات أن توفر اليد العاملة الماهرة و الإبداعية أو رأس المال البشري القادر علــى إدمـــاج التكنولوجيات الحديثة في العمل. وتتامي الحاجة إلى دمج تكنولوجيا المعلومسـات و الاتصالات فضلا عن المهار ات الإبداعية في المناهج التعليمية وبــر امج الــتعلم مدى الحياة. ب- البنية التحتية المبنية على تكنولوجيا المعلومات : و الاتـصالات تـسهل نشر وتجهيز المعلومات و المعارف وتكييفه مع الاحتياجات المحلية. ع- حوافز تقوم على أسس اقتصادية قوية : تستطيع توفير كل الأطر القانونية و السياسية التي تهدف إلى زيادة الإنتاجية و النمو . وتشمل هذه الـسياسات التـي تهدف إلى جعل تكنولوجيا المعلومات و الاتصالات أكثر إتاحة ويسر ، وتخفــيض التعريفات الجمركية على منتجات تكنولوجيا و زيادة القدرة التتافسية للمؤسـسات الصغيرة و المتوسطة.

0- العولمة: فإن سوق العمل لم بعد محصور ا داخل بلد بعينـــهـ فالــدول الأوربيــــة

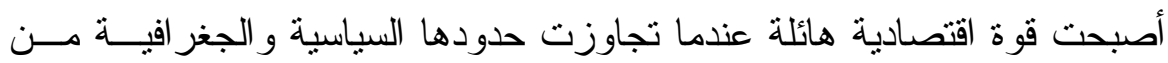
خلال الاتحاد الأوربي كذلك فالانتزنت أوجد اقتصاد بلا حدود و أصبحت الــدول الناهضة للتو تتحدى عمالقة الصناعة في الوصول إلى المــستهكين و الحـصـول على حصته من السوق في كل مكان في العالم ولم يقتصر التغيير علــى حــدود

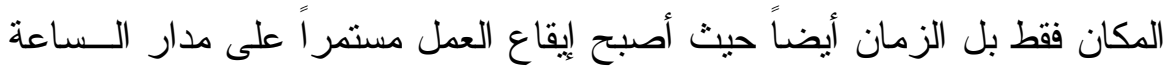
و أصبح الحد الأدنى لساعات العمل (ع r) ساعة في اليوم على مدار العام . 
توجه خولة قهر نحو اقتهات المعرفة

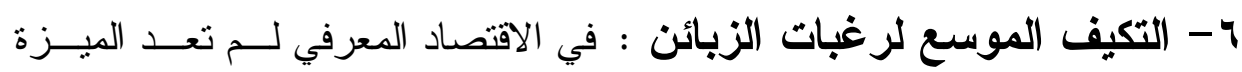
التتافسية تعتمد على الإنتاج المكثف و التشويق المكثـف و التوزيــع و الــسياسات

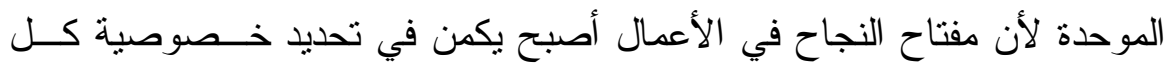

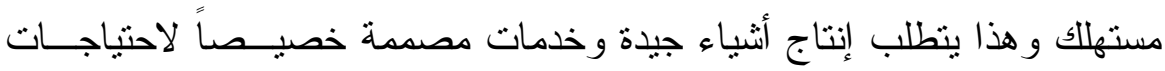

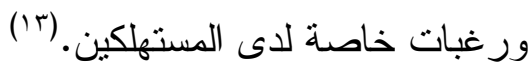

- V نقص الكو ادر والمهارات : في ضوء النمو الاقتصادي الحالي هناك العديـــ من الوظائف لاتجد من يملؤها وخاصة الوظائف التي تتطلب مهار ات في تقنيـــة

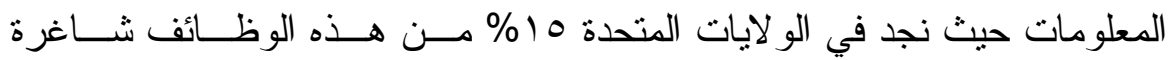

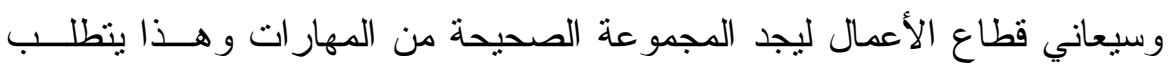

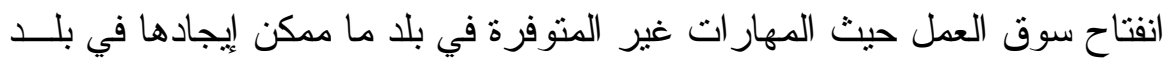
آخر وذلك من خلال الشبكات الاككترونية

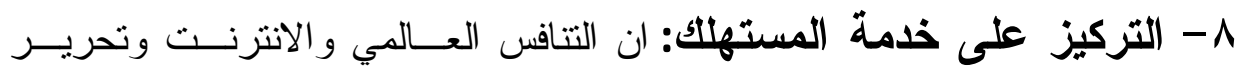
التجارة وزيادة إمكانية الوصول للمعلومات وتعدد الموزعين كلها عو امـلـل قـوة وضعف في يد المستهلك حيث أصبح المستهلكون هم أصحاب القــرار و الــر أي و هذا يتطلب خبر ات شاملة بالمستهلكين ورغباتهم وأن مبدأ خدمة المستهلكين هو الذي سيميز الشركات في القرن الحالي •

9 - التجارة الاككترونية : كلما تز ايد عدد مستخدمي الانترنت أصبحت التجـارة الالكترونية أكثر رسوخاً ويشمل ذلك التجارة الالكترونية التي تتم بين الـشركات نفسها أو بين الثركات و المستهلكين ويتوقع أن يصل حجم التجارة الاكترونية في

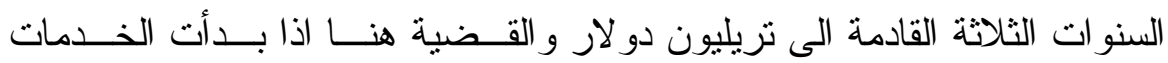

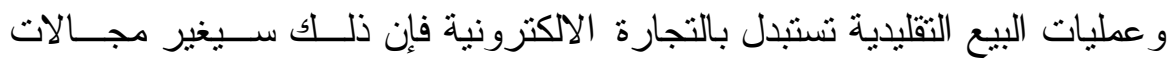
التوظيف من المو اقع التقليدية إلى الوظائف التي تتطلـــبـ مهـــار ات فـي تقنيــــة المعلومات 
• 1 - الحاجة للتعلم مدى الحياة: من المنوقع أن يزداد عدد المتعلمين الكبار أكثر

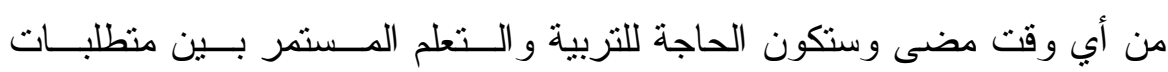
جوهرية للحفاظ على قدرة الفرد للبقاء في الوظيفة . 1 - المؤسسة في واحد : وهو ما يعني أن المؤسسات المستقبلية ستكون مسنـ عدد محدود من الموظفين و الإدار ات الأساسية وسيترك كل ماعدا ذلك لمــزودين

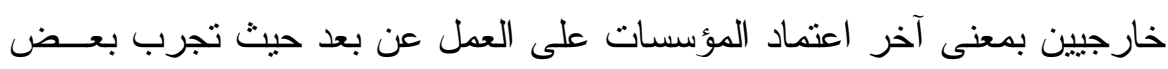

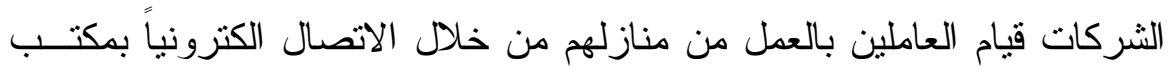

رئيسي. (1)

هذا الاقتصاد ينظِر إلى المعرفة على أنها مُحركُ العملية الإنتاجية وفي نفـس

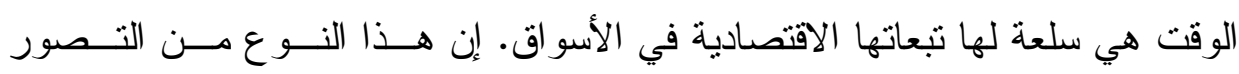

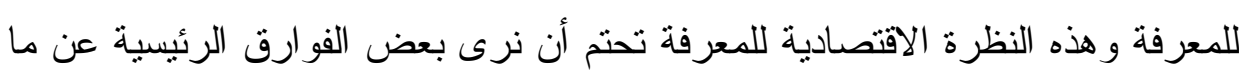
اعتاده الاقتصاديون في تتاولهم للسلع (10) فالمعرفة كسلعة لا يمكن لها أن تتضُب أو تتتهي وتتلاشى بسبب اســتخدامها

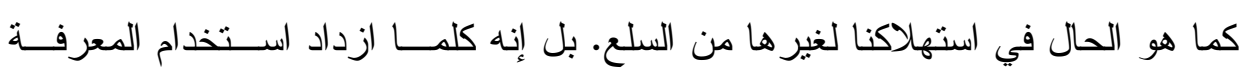

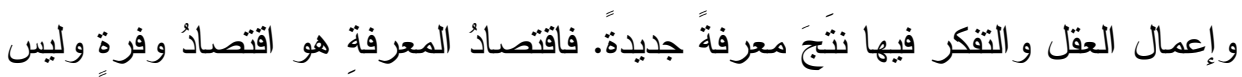

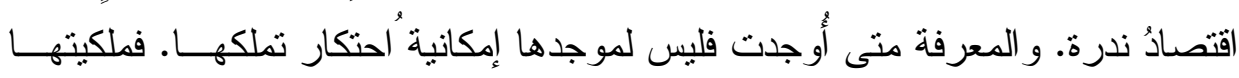

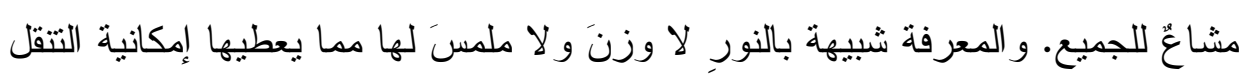
بكل سهولة.

\section{r ـ مقومات المجتهيع القائم على اقتصاد المعرفة}

تتعدد الرؤى المرتبطة بطبيعة مجتمع المعرفة، حيث تتباين محددات هذا المجتمع وخصائصه ، التي بعكسها الباحثٔون و المتخصصون في كتاباتهم حول هذا المجتمع، لذا

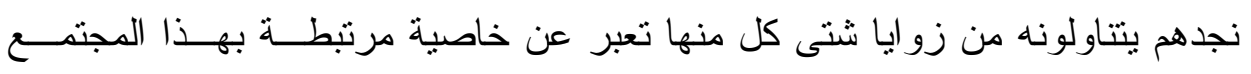

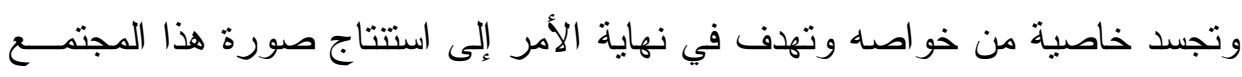

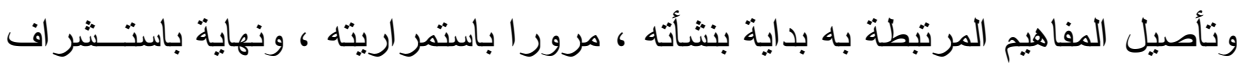


توجه خولة قهر نحو اقتهات المغرفة

رؤاه المستقلية، وتتمحور هذه الطروحات حول مفهوم شامل يؤطر لما يمكن ان يطلق عليه المقومات الأساسية لمجتمع المعرفة، تعكس رؤيه المتخصصين فــي التغييــر ات

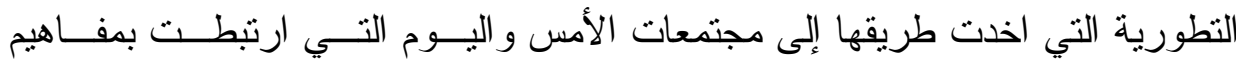

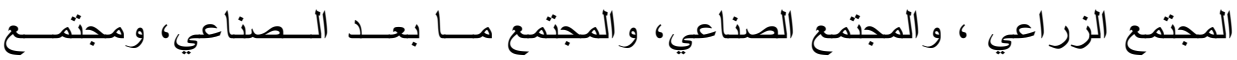
المعلومات ، ومجتمع ما بعد الحداثة لتحويلها الى مجتمعات تتبنى معـايير معاصــرة ترتبط بمفهوم مجتمع المعرفة، و المجتمع الرقمي يعــــ منعطفــا هامـــا فــي تــاريخ المجتمعات البشرية، وبداية لحقبة تطورية جديدة تتعامل مع معطيات ثقافية وتقنية غير مسبوقة للبشر بآفاق مستقبلية جديدة على مستوى الانجاز ات البشرية في كافة المجالات الحيوية المرتبطة بمجتمعات الغد.

ويستعرض الباحث في هذه الجزئية من الدراسة عددا من المقومــات الأساســية

لمجتمع المعرفة، كما وردت في أدبيات المجال

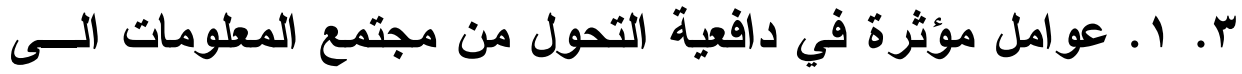
مجثمع المعرفة. و لابد في البداية الإشارة إلى أن هنالك فروقات جوهرية بين مجتمع المعلومات

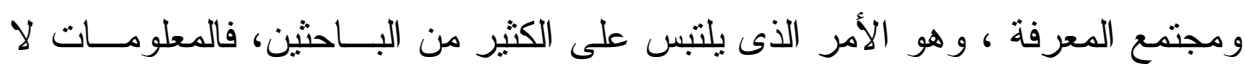
تتكل ألا جزءا من الثورة المعرفية التي تقوم على مجالات العلم و التقدم التكنولـــوجي التهري

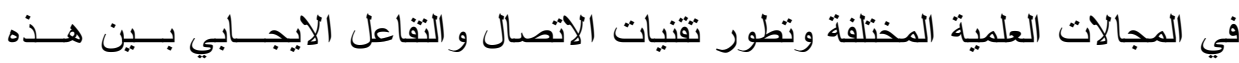
المجالات الثلاثة لتضع في النهاية رؤية معرفية شاملة تتعدى بكثير الرؤية المعلوماتية التي كانت سائدة من قبل. وقد تتاول الكثير من الباحثين الدافع وراء تحـــول مجتمعــات الحاضــر الــى مجتمعات تدين بمفاهيم جديدة مرتبطة بصورة أكبر بمفهوم المعرفة بمعناها المعاصــر ، حيث تشكل المعرفة وتداعياتها الفكرية و التكنولوجية أبرز مكامن القوة وتضعنا إز اء شكل جديد من التطور المجتمي يعتمد في بسط سيطرته ونفوذه على المعرفة بإطلاقها و على المعرفة العلمية منها بشكل خاص. 
وقد ذكرت حسانه محي الدين('1) أن من العوامل التي بدأت تدفع بالتحول مـن مجتمع المعلومات إلى مجتمع المعرفة: ا ا. سرعة دوران الزمن مع النطور النقني r. التتافس الكبير بين المؤسسات و الثركات الإنتاجية و الخدمية r. قلة التتبؤ بما سيجري خلال فترة قصبرة ع. أ وجود مجتمعات افتر اضية 0. ت تغيير في بيئة الأعمال و الإدارة قد ركزت في طرحها على أن هذه العو امل دفعت المجتمعات إلى الاعتماد على

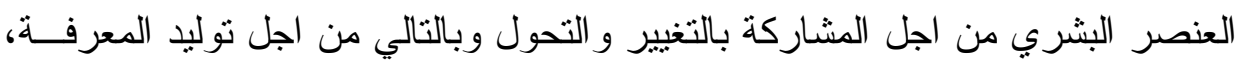
و هذه الرؤية تركز إلى حد كبير على العنصر البشري و المؤسسي ودورهما في عملية التحول. ويسنطيع الباحث أن يضيف إلى هذه العو امل:

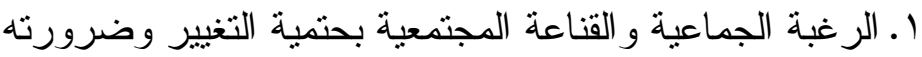

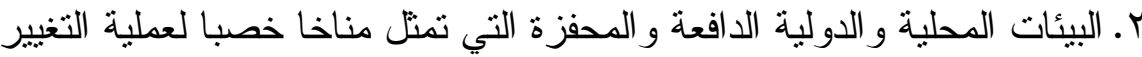

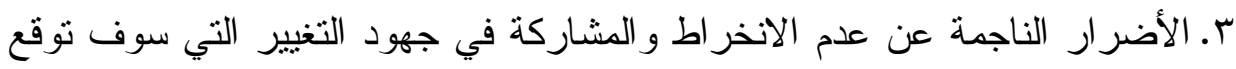
المجتمعات غير المشاركة في هذه العملية الى التخلف و الانزواء وعدم الانــضمام

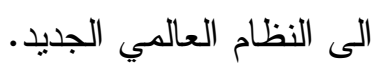

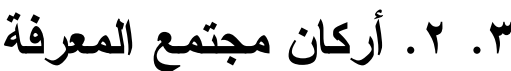

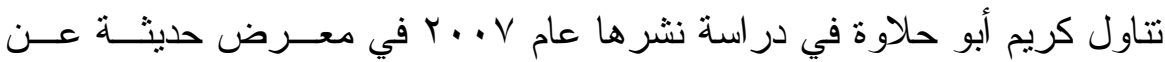

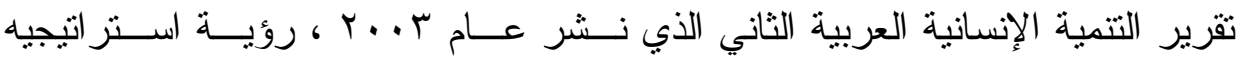
تضمنها التقرير حول الأركان الأساسية لمجتمع المعرفة جاء فيها: "تتضمن الأركسان

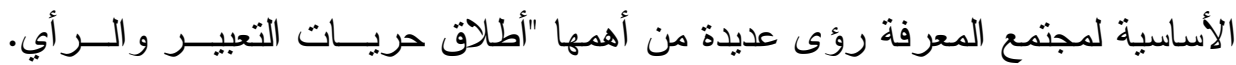

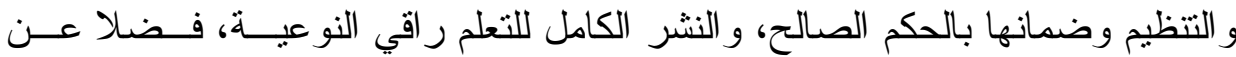
توطين العلم وبناء قدرات ذاتية في البحث و النطوير التقني وصو لا إلى تأسيس نموذج

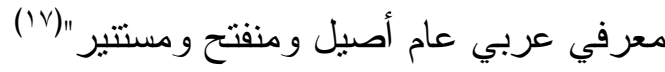


توجه خولة قهر نحو اقتهاخ المعرفة

ويصو غ محسن خضر أركان مجتمع المعرفة في صورة نقاط محــددة تــلخص

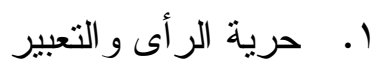

r. تشر وتعميم التعلم وردم الفجوة المعلوماتية

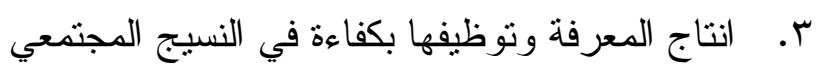

ع. أبدع نموذج معرفي ذي خصوصية نقافية

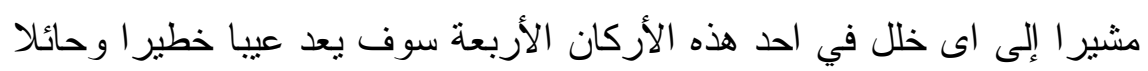

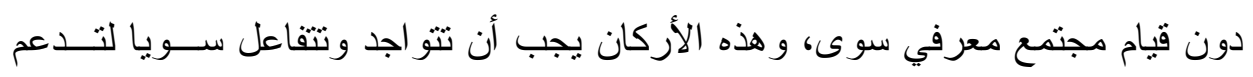

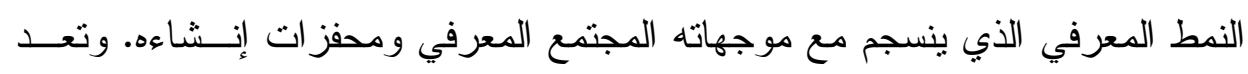
مجموعة هذه الأركان من وجهة نظر الكاتب احد التحديات التي تقابـلـل لـبـس العــالم العربي فحسب بل دول الجنوب على وجه العموم، الذي يفتقد في كثثر من الأحيان احد هذه الأركان ، وفي اغلب الوقت معظمها.

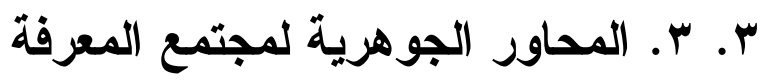

تعد محاور مجتمع المعرفة من المقومات التي تهم المؤسسات الدوليــة المعنيـــة

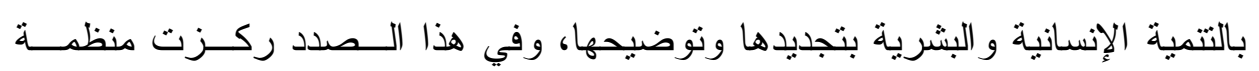

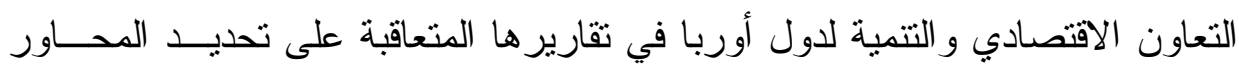
الرئيسية لمجتمع المعرفة، وتضمنت تقرير ها في هذا المجال على عدد مــن المحسـاور

$$
\text { تلخصت في: }
$$

1. تحقيق مناخ اقتصادي منفتح ومستقر بأسو اق تعمل بفعالية

r. نشر تكنولوجيا الاتصالات و المعلومات r. ع. دعم الابتكار و الإبداع ع. الاستثمار في رأس المال البشري

في نفس الوقت السياق الموضوعي ، و التوجه الاستر اتيجي ، أعدت دول منظمة

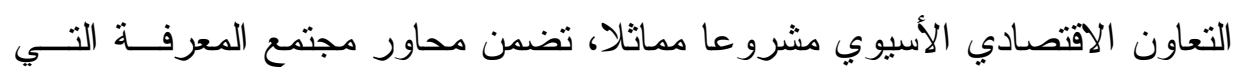
لخصها في خمس محاور : 


$$
\text { ا ـ التطوير التكنولوجي }
$$

r. أيجاد نظام نوعي فعال يشجع على الابتكار

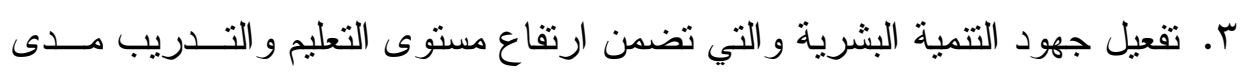

$$
\text { الحياة }
$$

ـ. تشييد بنية تحنية فعالة لتكنولوجيا المعلومات

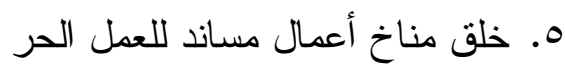
أما على الصعيد العربي منذ اعتمد مجلــس الــوزر اء العربــي للاتــــالات و المعلومات أطار لخطة لعمل مشترك لبناء مجتمع معرفي عربي متضمنا محاور بناء هذا المجتمع التي تضمنت النقاط التالية: ا ـ خلق القناعة بدور تكنولوجيا المعلومات و الاتصالات في التتمية r. خلق بيئة مواتية وسريعة الاستجابة r. بطويع السياسات و التشريعات ـ. التخطيط للاندماج و التكامل الإقليمي بين دول العالم العربي 0. الفضاء الثامل للمعلومات و المعرفة وتتمية الموارد البشرية 7. المحافظة على نر اث المعلومات ودعم المحتوي المتنوع ثقافيا و المتعدد لغويا V. إذكاء روح البحث و التطوير

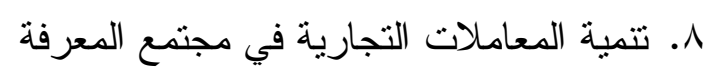
9. التعاون و التمويل المشترك في مجال تكنولوجيا المعلومات و الاتصالات

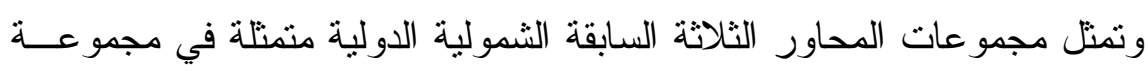

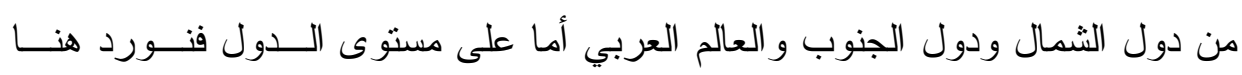
نموذجان احدهما يمثلان وجهتي النظر ولكن على المستوى القطرى للدول حيث نورد

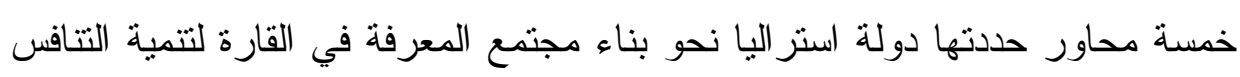
الدولي و الرخاء الاقتصادي و الاجتماعي للاولة الاستر الية حيث تضمنت:

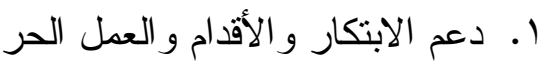
r. الاستثمار في رأس المال البشري

$v \cdot$ 
توجه خولة قهر نحو اقتهات المعرفة

r. نشر تكنولوجيا الاتصالات والمعلومات ع. توفير المناخ المساند للمعرفة ه. قياس اثر التوعية نحو التوجه على الاقتصاد و المجتمع و على الجانب الآخر فإن ما أعلنته الحكومة المصرية في مبادرة نحو بناء مجتمع المعرفة يعتمد على عدة محاور منها:

$$
\begin{aligned}
& \text { ا ـ. الاستعداد الرقمي } \\
& \text { r. الحكومة الاككترونية } \\
& \text { r. التجارة الالكترونية } \\
& \text { ع. التعلم الاككتروني }
\end{aligned}
$$

ه. الخدمات الالكترونية لقطاع الصحة

7. التوثيق الالكتروني للتز اث الحضاري

V. تتمية صناعة تكنولوجيا الاتصالات و المعلومات (9. (1)

ومن البديهي فمهما تعددت وجهات النظر واختلاف الصياغات التي حررت بها

هذه المحاور فأنها تدور حول فكرة واحدة ومفهوما ثابتا ويعود في النهاية الى كيفيـة

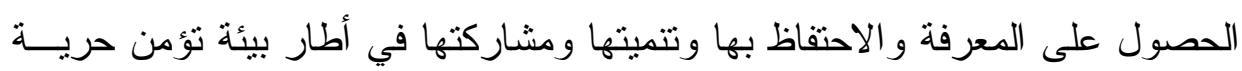
الر أى، وقوة العلم و إمكانية التغيير مع الحفاظ على الهوية الوطنية و الثقافية للمجتمــع لئه

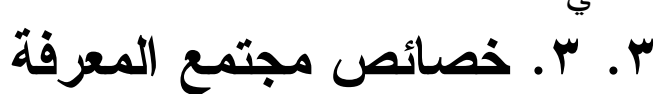

عاصرت البشرية و الحضار ات الإنسانية المتعاقبة أنو اع شتى مــن المجتمعــات

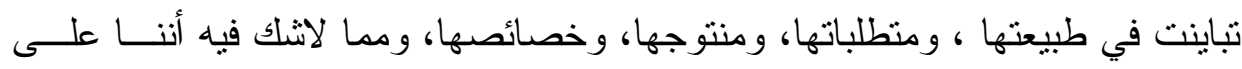

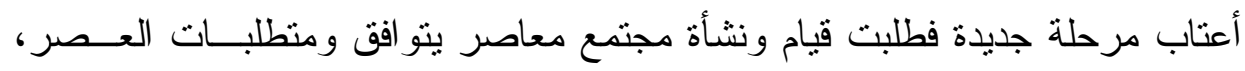

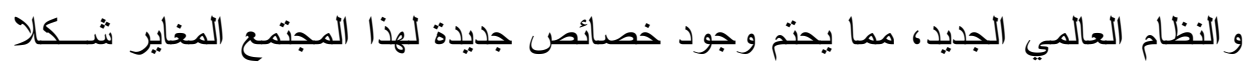
و مضمونا عما سبقه من مجتمعــات، لــذا اجتهــدت الــدو ائر المعنيــة بــالتغيرات المجتمعية،وباحثي الجمال في وضع تصور لخصائص هذا المجتمع الجديد، وكان من الطبيعي أن تختلف وجهات نظر ا جمهرة الباحثين وقد تلتقي على الخــصائص التـي 
يتميز هذا المجتمع أو من وجهات النظر الثمولية في هذا الخصوص، ما أورده كــريم

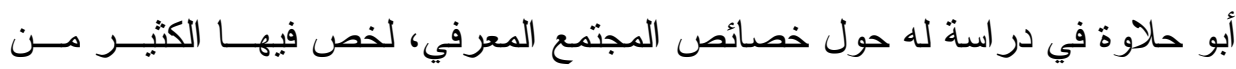
وجهات النظر حول هذا الموضوع، وأورد خصائص عامة مميزة لمجتمع المعرفــة،

$$
\text { 1- الانفجار المعرفي }
$$

يعيش العالم انفجار ا معرفيا غير مسبوق بحيث يندر أن يمر يوم أو شهر دون

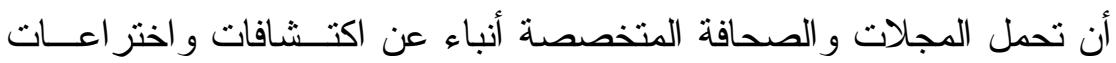
جديدة في مجال الالكترونيات، ... وتثشير المعطيات الــى أن البـشرية قـــ ر اكمت في العقدين الأخيرين من المعارف مقدار مار اكمت طوال الآلاف من

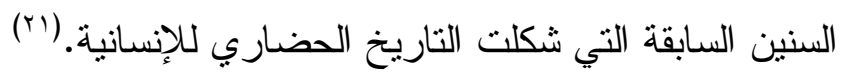

$$
\text { r- r - r الشارع }
$$

كان التغير وماز ال سنة الكون وقانون الوجود الأبرز، وحيث أن التغيير فــي فجر التاريخ كان بطيئا وغير ملحوظ فأنه حاليا يتز ايد سرعته و استمر اره.... ومن ناحية أخرى تقلصت الفترة الزمنية بين ظهور الفكرة وبين تطبيقهـا . .

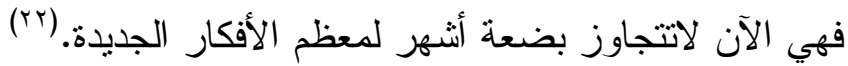
ب- التطور التكنولوجي

عندما نتحدث عن تطبيق الأفكار وتحويلها إلى أدوات وسلع وخــدمات فإننـــا التكنولوجيا / التقنية و التكنولوجيا ذات طبيعة اقتحامية وتحويلية ولعـلـ أهـــ التطور ات التكنولوجية التي شهدها العالم في العقود الأخيرة تمثلت في طيران مفرط الصوتية ، و الهندسة الجينية و الثقافة الحيوية بآفاقها الو اعدة ، و المـــواد المخلقة الجديدة التي لم تكن موجودة في الطبيعة، وتطبيقات الليزر و غيرهــا، و الاندماج بين ثورة الاتصالات والكمبيونز مع أمكانية الاتصال اللحظي التي تسمح بالحوار عبر المحيطات، وتز ايد أيتاح المعرفــة وتوليــدها واكتـشـافها المتو اصل من الخزن اللانهائي و الاعتماد على هذه المعرفة في أنتاج وتوليـــ 
توجه خولة قهلر نحو اقتهات المحرفة

السلع و الخدمات ومن الو اضح أن هذه الحقول التي تشكل أعمدة العلم الحديث

قد فتحت آفاقا غير مسبوقة في إمكانات التقدم في المستقبل.(rr) ع - انهيار الفواصل الجغرافية والتنافس في الوقت

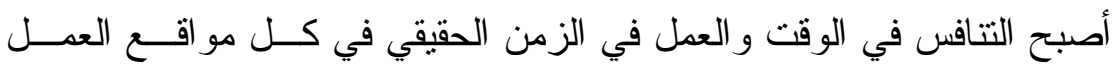
و الخدمات التي تعمل بلا توقف لتلبية احتياجات المستهلكين في جميع انحسـاء العالم هو السمة الأبرز للإنتاج بالرغم من الفو اصل الزمنية واختلاف التوقيت

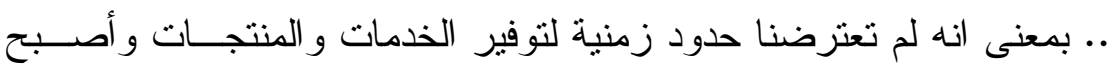
الناس في تتافس مفتوح في الفاعلية و الوقت. و على صعيد آخر تغيرت طبيعة الوظيفة و العمل عما كان عليه الحــال فـي ولي عصر الصناعة وقد غير شعار "اتصل و لاتتنقل" المفهــوم التقليــدي للعمــلـ

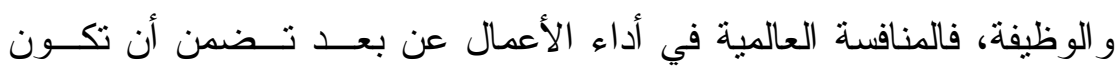
الأعمال في أعلى مستوى من الجودة و الكفاءة.

\section{ه - ارتفاع المكونات المعرفية وتضاعل المكونات المادية}

تتمبز المنتجات الجديدة بتوظيف كثيف للمعلومات و المعارف وتتضائل شــيئا

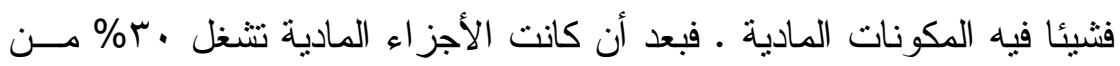
قيمة المنتج، فإنها وصلت إلى حوالي · ( \% ، وينتظر أن تتخفض إلــى اقـلـ

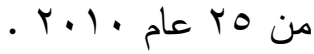
وتعود الأسباب الكامنة ور اء هذا التحول إلى المواد الجديدة المختلفــة والــى تز ايد قيمة المكون المعرفي في المنتج ، و الى ارتفاع تكلفة البحث و التطــــير

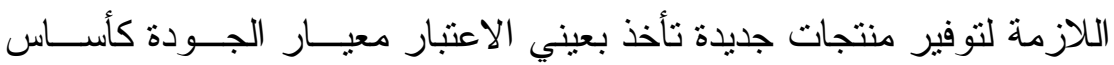

ل ل لمنافسة.

צ- نموذج إرشادي جديد

لاتقتصر نتائج التحو لات المر افقة لعصر المعرفة ومجتمــع المعرفــة علــى مايمكن أن ينتج عنها من آثار مباشرة وغير مباشرة فحسب، بل تتصل بتغيير المرجعيات و الأسس و القو اعد التي ترتكز عليها تطور المعرفة نفسه. 
و هذا التغيير سيفرض الى مرحلة الثورة العلمية ، حيث يتم استبدال النمــوذج

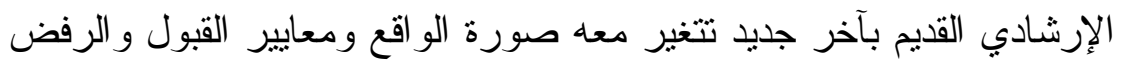

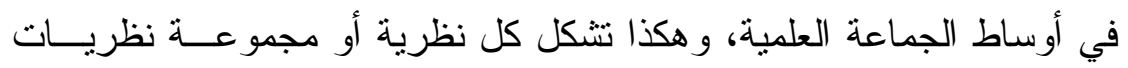

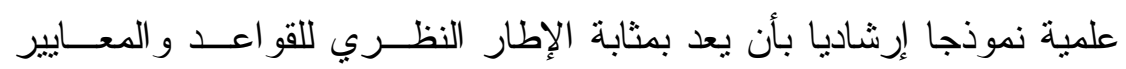

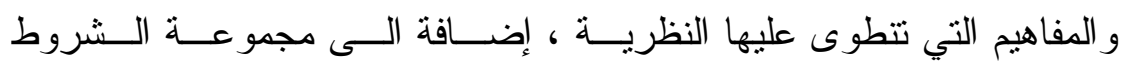
الاجتماعية و النفسية و التاريخية.

و التساؤل المطروح الآن على الساحة الدولية والمحافل العلمية على تباينها، أين نحن من هذا التطور العاصف للعلم و التكنولوجيا؟ ، ومــن هـــا الطـــرح العــريض

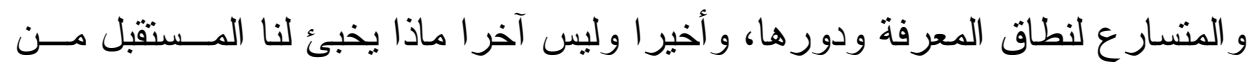

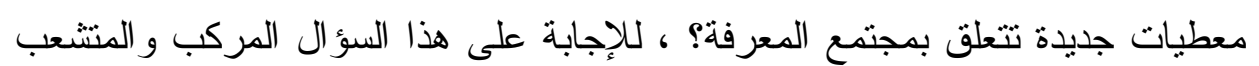

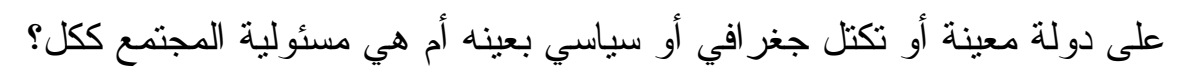
r. ع. ع. أبعاد مجتمع المعرفة

يتفق الباحثون بمختلف مشاريعهم على أن هناك أبعاد محددة لمجتمع المعرفة يجب التعرف عليها و الإفادة منها، ومن الضرورى على من يود الانخر اط في النظــام الدولي ان يستو عب هذه الأبعاد ويعييها ، ويعمل على تطبيقها ، حتى لايصار تهميشه

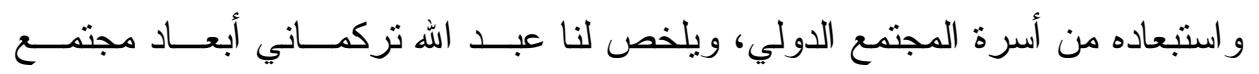

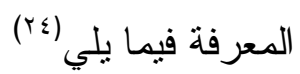
1- البعد الاقتصادي

تعد المعلومة في مجتمع المعرفة هي السلطة أو المخزون الرئيسية و المصدر

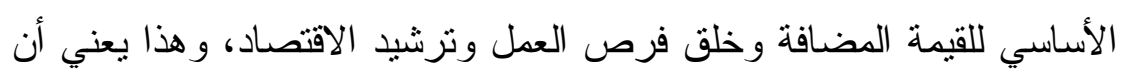

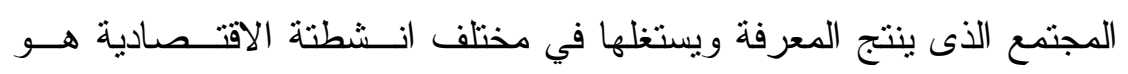
المجتمع الذى يستطيع ان ينافس ويفرض نفسه.

r- البعد التكنولوجي

أن حجم المعرفة يعنى انتشار تكنولوجيا المعلومات وسيادتها وتطبيقهــا فـي مختلف نواحي الحياة ، كما يعنى ضرورة الاهتمــام بالوســائط الإعلاميــة 
توجه خولة قهر نحو اقتهات المعرفة

وتكبيفها وتظويعها حسب الظروف الموضو عية لكل مجتمع سو اء فيما يتعلــق

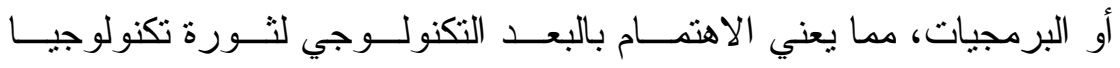
الاتصالات وتوفير البيئة الأساسية لإقامة شبكة منقدمسـة لوســائل الاتـصال

وجعلها في منتاول الجميع

ب- - 1البعد الاجتماعي

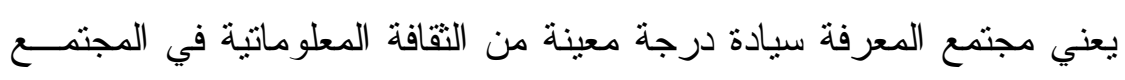

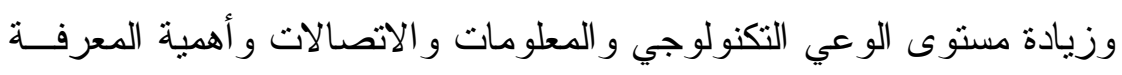

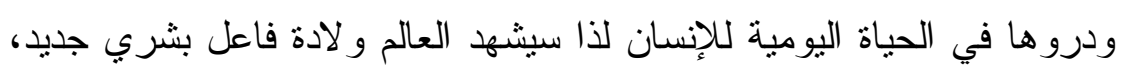

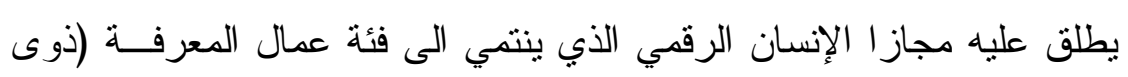
الياقات البيضاء) مما سيطرح مفهوما اجتماعيا جديدا هو " الصحافة المعرفية

$$
\text { " ( ل الئوى الياقات الذهبية) }
$$

ع - البعد الثقافي

من أهم أبعاد مجتمع المعرفة هو البعد الثقافي حتى بعد أعطاء أهمية قـصوى

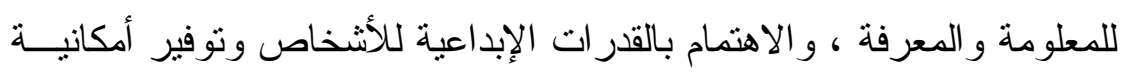

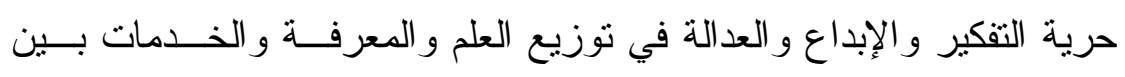

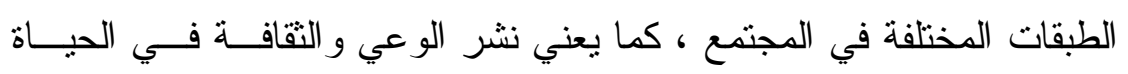
اليومية للفرد و المؤسسة و المجتمع ككل.

ه- البعد السياسي

من الأبعاد الأساسية في مجتمع المعرفة أثنر الك اتجاهين في اتخاذ القــرارات

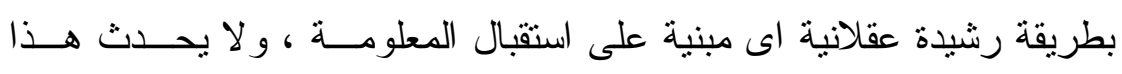
بطبيعة الحال ألا بتوسيع حرية تداول المعرفة، وتوفير مناخ سياسـي مبنـي علئي

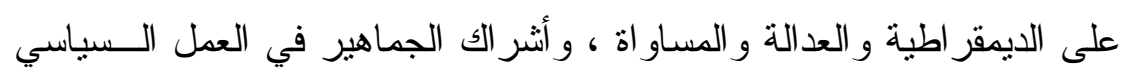
الفعال

ويرى الباحث أن مجتمع المعرفة لايقوم على اكتثاف المعرفة و إنتاجها وتــداولها و الإفادة منها ، أنما يحتاج الى مفاهيم ثقافية مختلفة مغايرة للمفاهيم التي كانت ســائدة 
في مجتمعات الأمس، بل وفي بعض مجتمعات اليوم، مفاهيم ثقافيــة تعتبــر الإنــسان جو هر المعرفة البشرية، ومبدعها ومخلقها، لما حباه الله به من عقل مستتير ومميـز ، ففضله على سائر مخلوقاته، كما يتحلى مجتمع المعرفة اجتماعية وسياسية بمعايير جديدة تؤمن بالمعرفة ودور ها و أهميتها في تعظيم المجتمعات و التسامي بمقر اتها بهدف

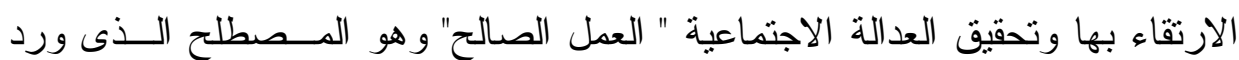
مؤخر ا في كتابات جمهرة الباحثين على مستوى العالم وبجميع اللغات.

\section{سمات المجتميع القائم على اقتصاد المعرفة:} - الاستتمار في الموارد البشرية باعنبار ها رأس المال الفكري و المعرفي . - الاعتماد على القوى العاملة المؤهلة و المتخصصة. - انتقال النشاط الاقتصـادي من إنتاج وصناعة السلع إلى إنتـــاج وصــــاعة الخــدمات

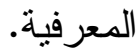
- اعتماد التعلم و التدريب المستمرين، و إعادة التذريب. - توظيف تكنولوجيا المعلومات و الاتصالات بفاعلية. - تفعيل عمليات البحث و التطوير كمحرك للتغيير و التتمية. - ارتقاع الدخل لصناع المعرفة كلما ارتفعت وتتوعت مؤ هلاتهم وخبر اتهم وكفاياتهم . - عقود العمل هي أكثر مرونة ومؤقتة ومرتبطة بالمهمة(ror) .

\section{فوائد وإيجابيات اقتصاد المعرفة :}

ا . يعطي المستهلك ثقة أكبر وخيار ات أوسع. r . يصل إلى كل محل تجاري ومكتب و إدارة ومدرسة. r. بحقق التبادل إلكترونياً. ـ . يغير الوظائف القديمة، ويستحدث وظائف جديدة. 0. يقوم على نشر المعرفة وتوظيفها و إنتاجها في المجالات جميعها.

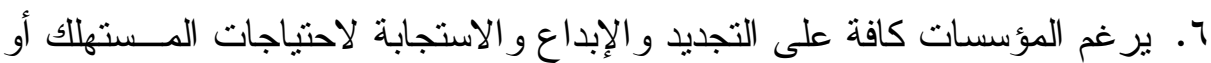
المستقيد من الخدمة. 
توجه خولة قهر نحو اقتهات المحرفة

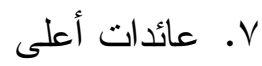

$$
\begin{aligned}
& \text { ^. عمالة منخفضة ونفقات منخفضة } \\
& \text { 9. انتشار أسر ع للمعلومات } \\
& \text { • (.تكلفة اتصالات منخفضة } \\
& 1 \text { ا .تكاليف تشغيل منخفضة } \\
& \text { rا.له أثز في تحديد: النمو، والإنتاج، و التوظيف، و المهار ات المطلوبة(r؟r). }
\end{aligned}
$$

\section{دور رأس المال البشري في اقتصاد المعرفة:}

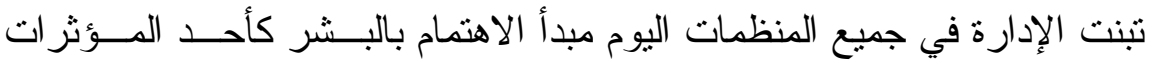

القوية التي تعطى ميزة تتافسية خاصة مع دخول القرن الواحدو العشرين الذي يركــز على اقتصاد المعرفة، و يعتبر أن إنتاجية رأس المال البشري هو المحك الرئيسي فــي لهي

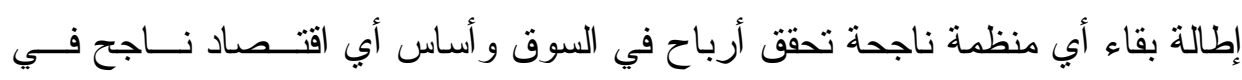

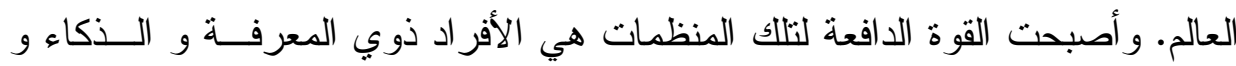
المهار ات التي تتلاءم مع منطلبات القرن الحالي. ولأول مرة في التاريخ يصبح لاى الجنس البشري قدرة هائلة على توليد أكبــر

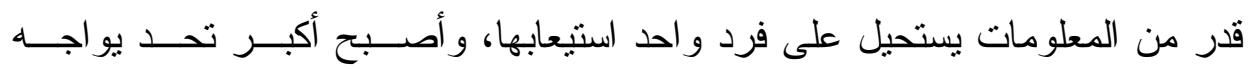

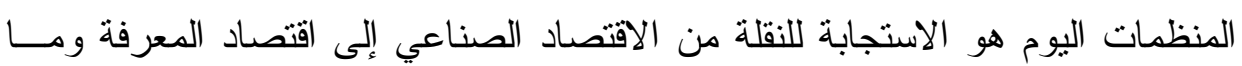
ينتج عنه من تغييرات جذرية في كل أوجه التنظيم الإداري من تشغيل وتسويق وهيكلة

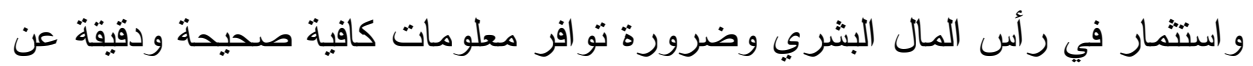
العنصر البشري حتى يمكن زيادة فاعليته في اكتساب المنظمات ميـزة تنـافـسية فــي السوق.

ورغم ما تتتجه تكنولوجيا المعلومات من بيانات وفيرة عن العنصر البشري في المنظمات، إلا أنه لا يتم استخدامها بطريقة سليمة في قياس العائد من الاســتمار فـي البشر • ونتيجة لذلك ظهرت الحاجة الماسة إلى وجود نظام قياس كمي ونوعي للمعرفة

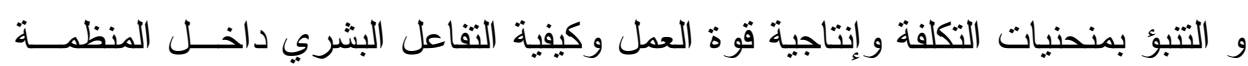
حتى تسنطيع الإدارة أن تقوم بما يل (rV) 
ا - معرفة ما الذي يدور داخل المنظمة؛ r- نوصيل توقعات الأداء المطلوبة للعاملين؛

ب- تحديد فجوات الأداء و التخلص منها؛

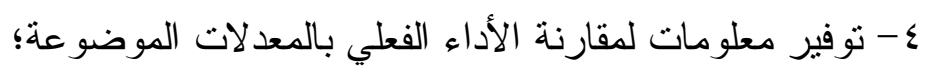

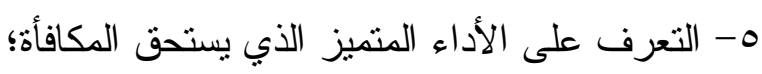

צ- تدعيم القرارات الخاصة بتسكين الموارد و الخطط و الجداول الزمنية. و يمكن إبراز الوجه الاقتصادي للعنصر البشري من خلال العناصر التالية: - يعتبر العنصر البشري وحدات اقتصادية وكيانات روحانية معا، فالأفر اد هي التـي

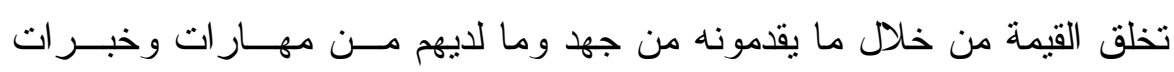
ودو افع داخلية وقد اقتصر قياس إسهامات البشر ولفتر ات طويلة علــى اســتخدام المقاييس المالية و القو اعد المحاسبية اعنقادا بأنها تعطي نتائج دقيقة. ومع تسليمنا بدقة الأرقام المالية إلا أنها مجرد أرقام تؤكد حقائق حدثت في الماضي وليس لها

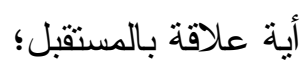
- كما أن القو اعد المحاسبية تتجاهل رأس المال البشري وتغفله من كـلـ حـساباتها كقيمة مضافة وتتظر إليه فقط كعنصر تكلفة. و اليوم ولثندة الحاجة للتركيز على لنى

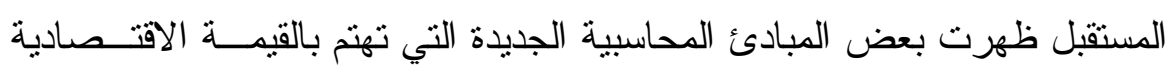

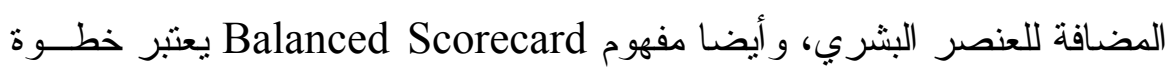
إيجابية في الاتجاه الصحيح لقياس فاعلية وقوة رأس المال البشري فـــي التـأثنير على الناتج الاقتصادي لكافة مجالات الأعمال (r^).

\section{العلاقة التمفاعلية ما بين الاقتصاد والتكنولوجيا في مجتهيع المعرفة:}

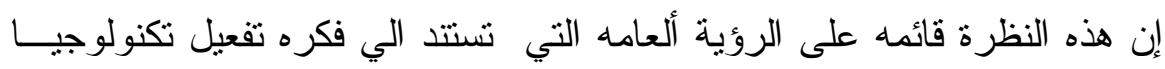

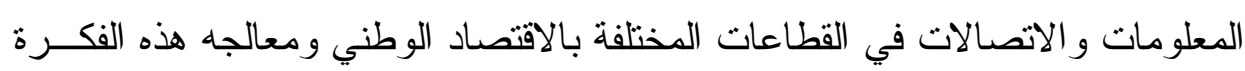
ر اسيا بكل قطاع علي حده, وتتحدث عن الاقتصاد القائم علي المعلومات أو المعرفة,

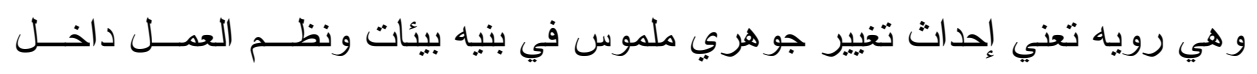


توجه خولة قهلر نحو اقتهات المحرفة

الاقتصاد نفسه أو لا وتعني أيضا أعاده هندسه أساليب الأداء وطرق التفكير التي تحكـم

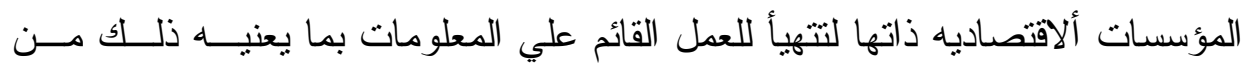
تطبيق حقيقي للعديد من الفلسفات و الأسـاليب الاداريه و هناك مبادئ من اجـل تغييــر فكري إداري اقتصادي يسبق أي تفكير:

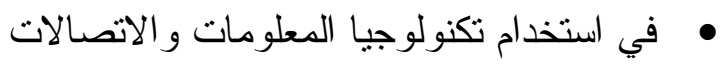

$$
\begin{aligned}
& \text { الأخذ بمبدأ الحرية } \\
& \text { • الثفافية في تداول المعلومات } \\
& \text { سرعه اتخاذ القرار }
\end{aligned}
$$

أز اله الالتباس وتضارب المصالح بين من يملكون المعلومات داخل الجهــاز

$$
\text { الإداري للاولة ومن يحتاجونها في تسيير إعمالهم اليومية. }
$$

$$
\text { إعلاء قيم العمل الجماعي }
$$

تقعيل ثقافة الجودة و العمل المخطط,

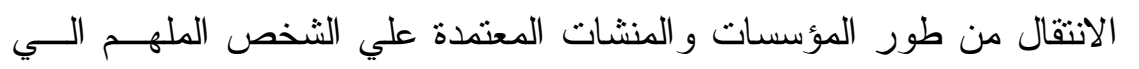
طور المؤسسات التي تفكر بمنهج علمي مستقر بعيدا عن الأثخاص والانفتاح

$$
\text { علي العالم بروي و اضحة (ra) }
$$

\section{مكونات الاقتصاد القائم على المعرفة :

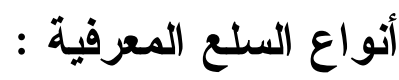

- المعارف العلمية: التقنية الفنية الإبداعية السياسية التاريخية ...الخ

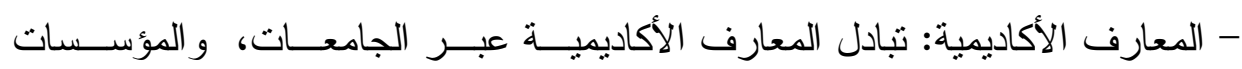
التعليمية

- المعارف الإعلامية : وهي كل ما يختص بإيصال الأخبار و الإعلان بكافة أثنكاله وسائط السلع المعرفية:

$$
\text { - الر ادليفزيون - }
$$


ك. خالض الحلبى

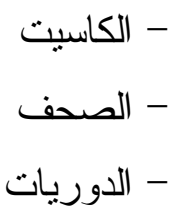

- الحاسب الآلي ومخرجاته الإكترونية و الورقية - الاقر اص المرنة و المدمجة - ماتب - الدوريات الإكترونية وأساليب النشر الالكتروني والانترنت

\section{الانترنت والبنية التحتية لاقتصاد المعرفة :}

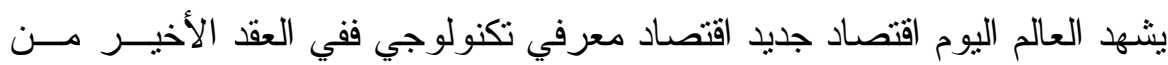

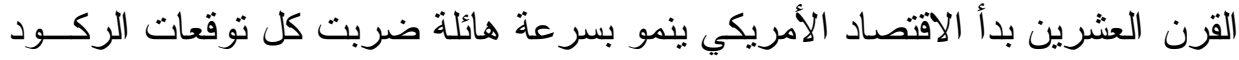

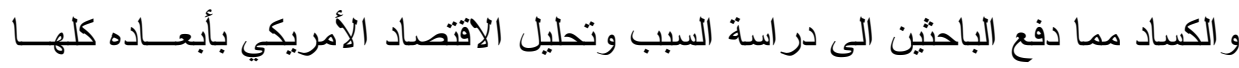
فلوحظ أن هذه الطفرة جاءت على خلفية النطور التكنولوجي الكبير الذي ظهر في كل التي

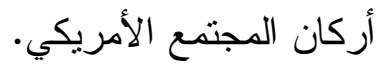

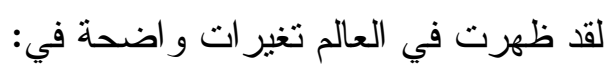

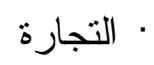

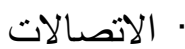

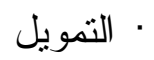

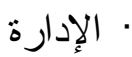

وتمثل الانترنت البنية التحتية لاقتصاد المعرفة كالتالي :

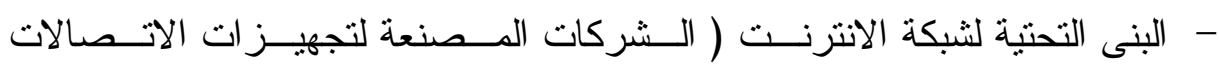

$$
\text { و الحو اسب و الخدمات ) }
$$

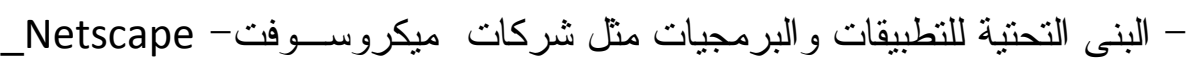

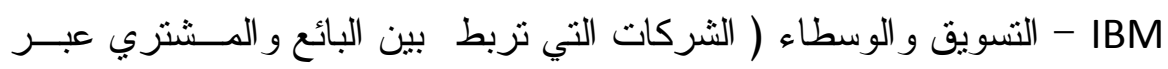

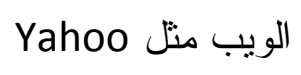

- بدأ اقتصاد الانترنت يحتل الموقع الأول بين القطاعات الاقتصادية.

$$
\wedge .
$$


توجه خولة قهر نحو اقتهاخ المعرفة

- هناك حو الي ه مليون شخص يعملون في تكنولوجيا المعلومات من خلال الإنترنت.

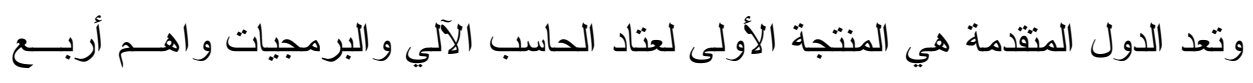
شركات في العالم هي: - مئ • ميكروسوفت القيمة السوقية . . 7 بليون دو لار

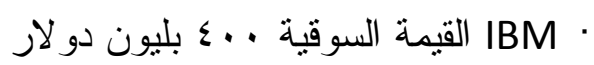
AT,T .

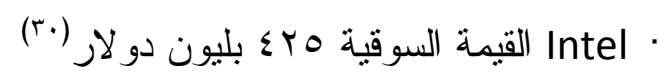

\section{بعض الأمثلة على استخدامات الإنترنيت اقتصاديًا :}

- باعت شركة أمازون مئات الآلاف من الكتب عبر الإنترنيت عام 997 ام ما يقارب

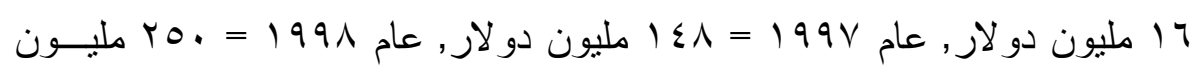
دو لار. - حجز تذاكر السفر ونسبة العمولة عليها عن طريق الوكيل تــتم بكلفــة م دو لار ات,

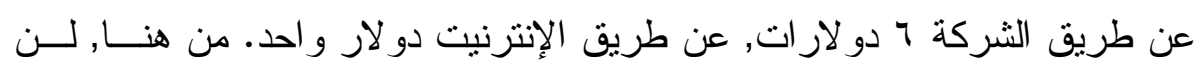

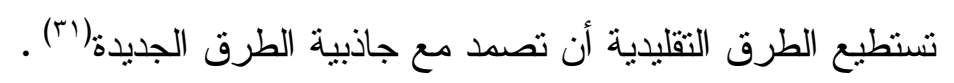

\section{[9] اقتصاد المعرفة عالمياً وعربيًا : \\ أ - على المستوى العالمي : ألهيل}

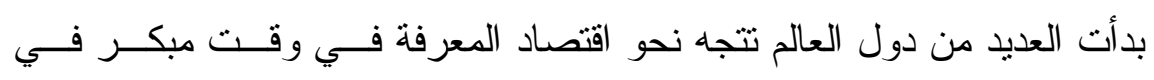
النصف الثاني من القرن العثرين(rr):

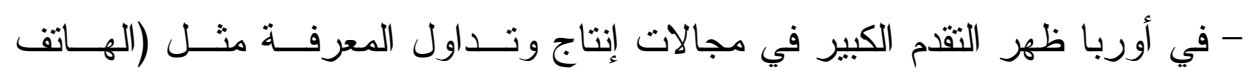
المحمول - الإنترنت - الإعلام - الإعلان - الدمج المعلوماتي..).

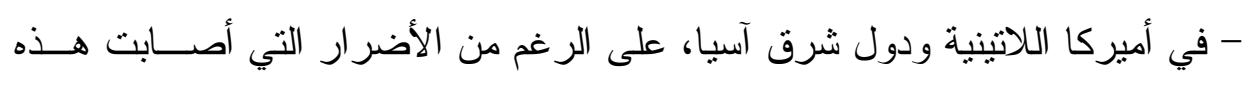

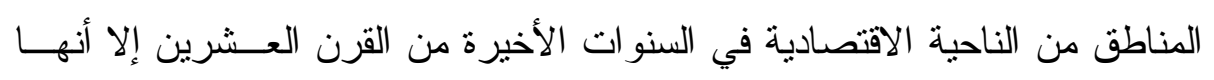

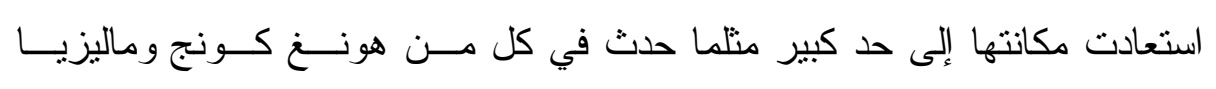
وفنزويلا. 
- نجحت الهند في بناء صناعة برمجيات عالية اســنطاعت بهــا أن تـستحوذ علـى

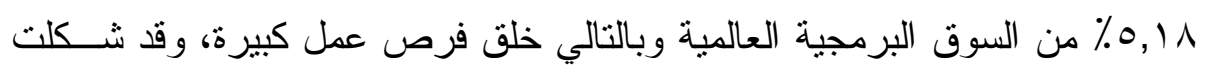

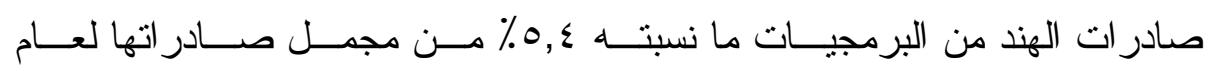
- 999 ام و هي في تز ايد مستمر

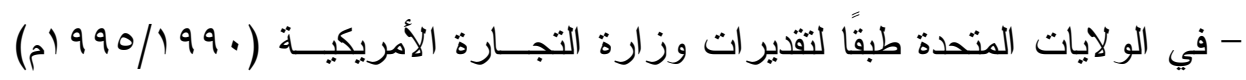

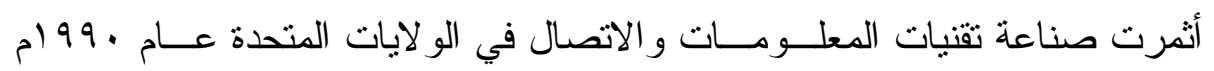
عائدات قدر ها rی1 ألف مليار دولار.

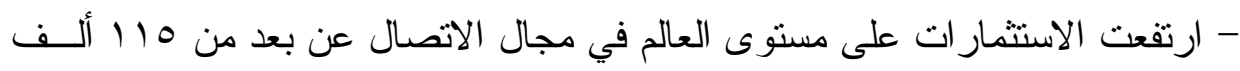
مليون دولار في عام • 199 إلى 10 ألف مليون دولار في سنة 990 ام.

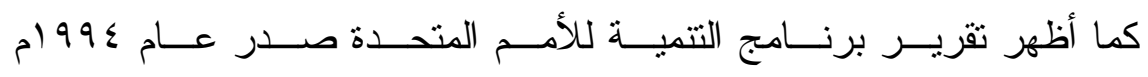
Development Report Human سنغافورة أو هونغ كونغ أو المجر, كان يشكل أكثر من • ؟ ٪ من النشاط الاقتــادي

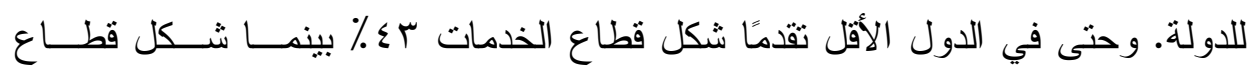

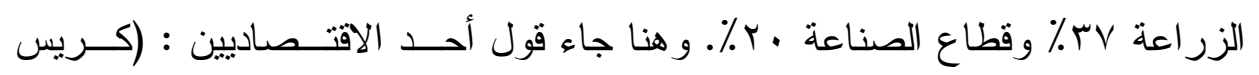

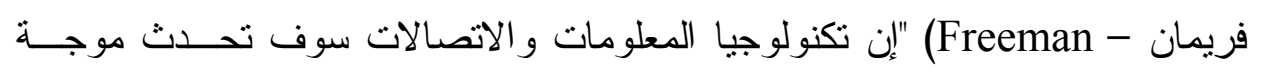

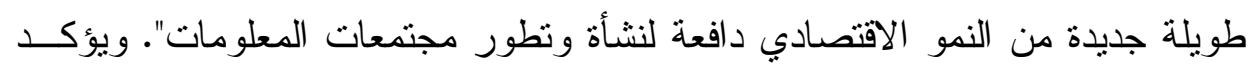

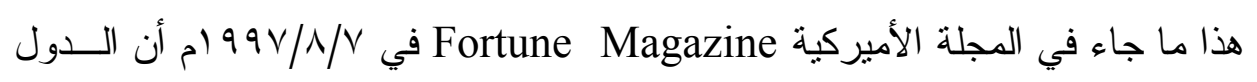
الصناعية الكبرى السبع (الو لايات المتحدة, اليابان, ألمانيا, فرنسا, بريطانيــا, إيطاليــا,

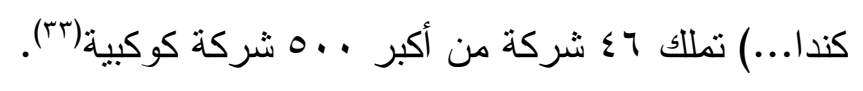
ب - على المستوى العربي :

بقي اقتصاد العالم العربي لحقبة طويلة من الزمن مرتبطًا بشكل عضوي بأســعار

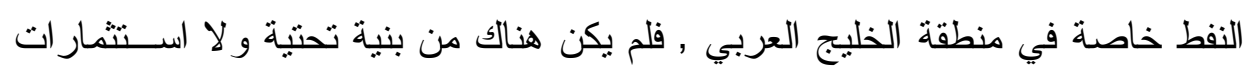
و لا قو انين نو اكب التطور التكنولوجي.

المجتمع العربي لم يستعد بعد للاخول في زمرة مجتمعات المعلومات على الرغم

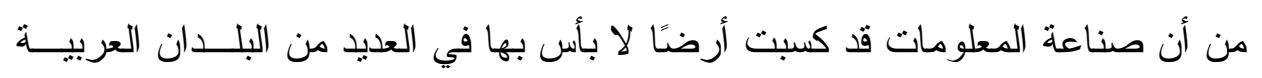


توجه خولة قهر نحو اقتهات المعرفة

بالبداية (لبنان - الإمار ات العربية المتحدة - مصر ...) إلاّ أنها لا تز ال في مراحـل

إن الاهتمام العربي بصناعة المعلومات ينحصر في دعامنين : - صناعة البر امج و الاتصال بشبكات المعلومات. - صناعة الإلكترونيات الدقيقة وأجهزة الحاسب الآلي :

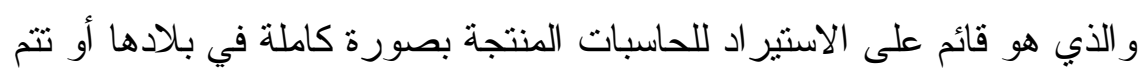
عمليات تجميع فردي بعد استير اد مكونات الحاسبات بصورة كاملة من بلادها.

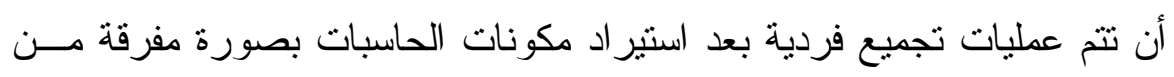
الأسواق المختلفة.

أن • ^^٪ من قيمة الاستشار ات و التصميمات في عالمنا العربي يوكل إلى بيــوت

الخبرة الأجنبية.

التبادل الأفقي بين البلدان العربية في مجال المعلوماتية يكاد يكون غائبًا. وأسبابه متعددة لعل أبرز ها : - ضعف البنى التحنية. - مصدر الموارد البشرية و المادية. - غياب السياسة الوطنية. - محدودية حجم السوق العربي الذي يصعب فيه اجتذاب رؤوس الأمو ال الوطنية

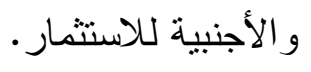

ثالثاُ تحول دولة قطر نحو الاقتصاد القائم على المعرفة:

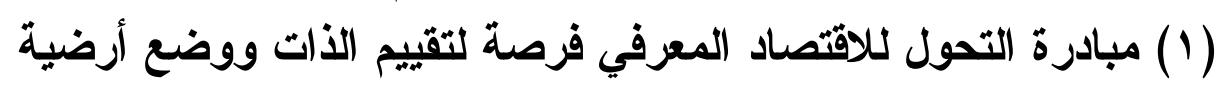

للتنسيق:

قال الثيخ حدد بن جبر بن جاسم آل ثاني رئيس جهاز الإحصاء والمدير العام

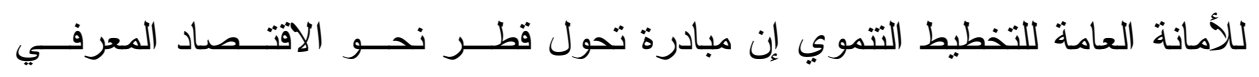

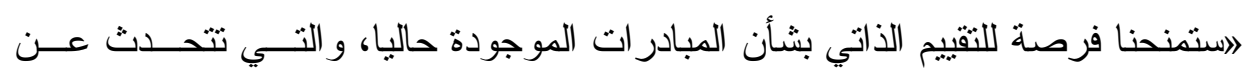


خ. خالت الحلبى

الاقتصاد المعرفي، كما ستشكل فرصة للربط و الوصل بين هذه المبادر ات، وهذا هــو

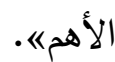

و أضاف الثيخ حمد بن جبر بن جاسم آل ثاني -في رده على أسئلة الصحافيين

على هامش ورشة مناقثنة مسودة خطة عمل تحول دولة قطر نحو الاقتصاد المعرفـي التي نظمتها الأمانة العامة للتخطيط التتموي- أن الهدف من هذه المبادرة يكمــن فـي هـي وضع أرضية صلبة بغرض التعاون و التسيق بين الجهات المعنية بالاقتصاد المعرفي، وتفعيل عملية ربط المجتمع بهذا النوع من المبادرات المتعلقة بالتوجه نحو الاقتـــاد المعرفي.

وأوضح الثيخ حمد بن جاسم آل ثاني أن الورشة تسعى إلى إجر اء ثقييم ذاتـي

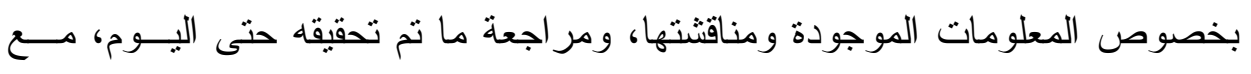
تحديد التوجهات المستقبلية، ووضع خطة عمل متفق عليها من قبل القطاعات المعنية،

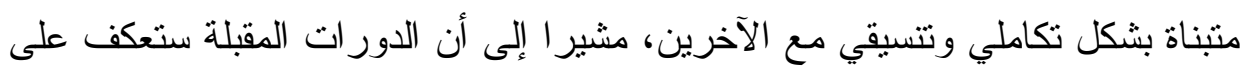

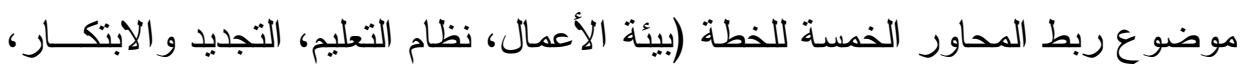
البنية التحتية للاتصالات، الحكم النموذجي)، ومن ثم صياغة ورقة و اضحة مــع كـلـ الجهات المعنية، والأهم من هذا تفعيل دور المجتمع للتوجه نحو الاقتصاد المعرفي.

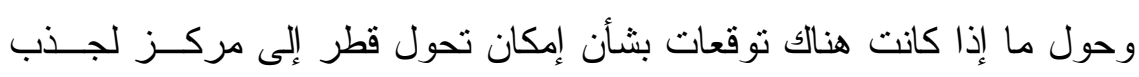
الصناعات المعرفية داخل منطقة الشرق الأوسط، قال الثيخ حمد بن جبر بن جاسم آل آل ثاني إن قطر بادرت بإطلاق عدة خطط أعطت مؤشر ا واضحا على جديتها في تعاطي موضوع الاقتصاد المعرفي، ومثَّل لذلك بمبادر ات مؤسسة قطر للتربية و العلوم ونتمية

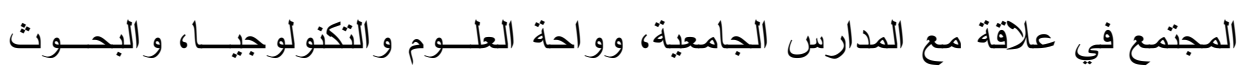

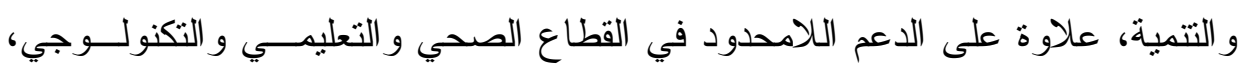
ونقل عن مسؤولي البنك الدولي كون مؤشرات قطر في الاقتصاد المعرفي تظل جيدة،

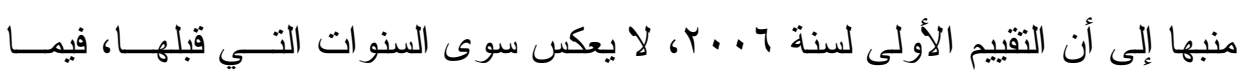
شهدت قطر تطور ا خلال المرحلة الحالية، وأن المسودة التي يجري مناقشتها مع البنك لأك الدولي ستدعم هذا التوجه الثمولي. 
توجه خولة قهر نحو اقتهات المعرفة

وحول ما وصف بـ 》الانتقاداته التي وجهها البنك الــدولي بـشأن ضــــف

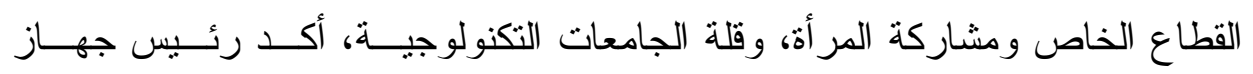

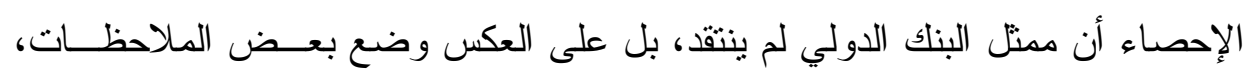

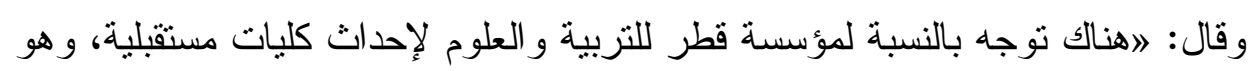
ما أثنار إليه ممثلو البنك الدولي أنفسهم،، وأضاف أن مشاركة المر أة في القطاع العام أكبر من مشاركة الرجل، وأن هناك مبادر ات متعددة لتفعيل دور القطاع الخاص فــي

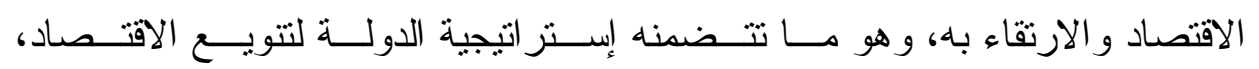
و استر اتيجيات أخرى ترى النور في الفترة المقبلة(؟َ) . (Y) خطة تحول قطر نحو الاقتصاد المعرفي:

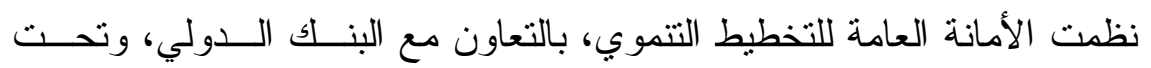

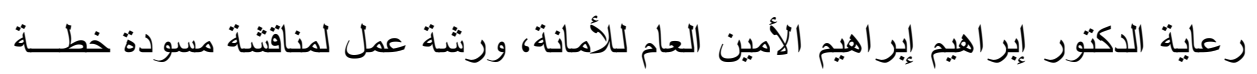

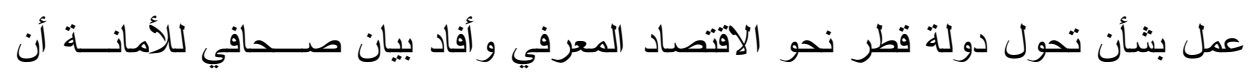

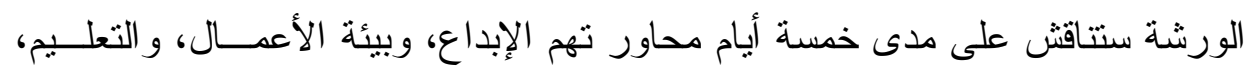

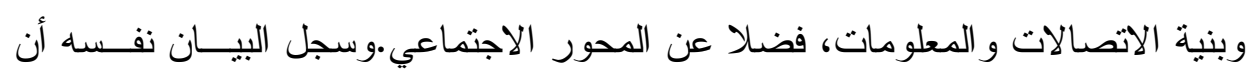

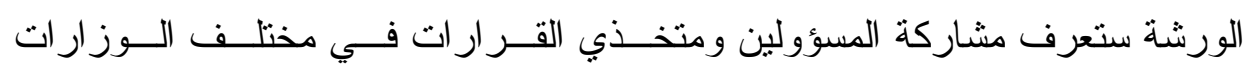
و الأجهزة الحكومية والمؤسسات التعليمية و القطاع الخاص ومنظمات المجتمع المدني، بالإضافة إلى الخبر اء المحليين و الدوليين.

و إن تتظيم الندوة يأتي تماثشيا مع ما يحتله التحول نحو الاقتصاد المعرفي مــن

أولوية في مختلف دول العالم، وفي سياق جهود التعرف على جاهزية قطر لذلك، ومن ثم وضع خطة عمل لإنجاز هذا المشروع. وبالاضافه ان الورشــة ركـزت وبــشكل

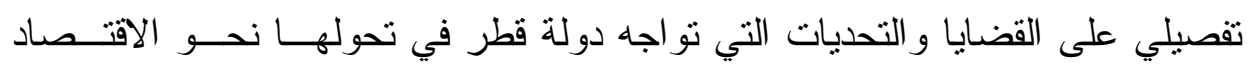
المعرفي، عبر التحليل الدقيق لكل محور وعرض التجــارب الناجحــة ذات العلاقــة، مشير ا إلى مساهمة خبر اء البنك الدولي في تتسيق أعمال الورشـــة و المـسـاعدة علـى ولى تدارس ما ينبغي عمله في تلك المحاور و اختيار البدائل الممكنة لذلك. 
وفي موضوع ذبي صلة استضافت الدوحة خــلال الفتـرة || - I ا فبر ايــر

الماضي ، مؤتمر الصناعات المعرفية لتقنيات النانو، تحت رعاية سمو الثيخ حمد بن

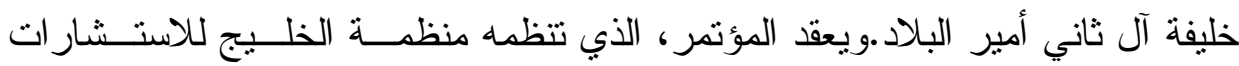
الصناعية التي يوجد مقرها بالدوحة، تحت شعار لانحو اقتصادات عربيـــة متطـــورة تحركها الصناعات المعرفيةه.

وان تتظيم هذا المؤتمر يأتي من منطلق وعيها بالدور الريادي الــذي يتوجــبـ

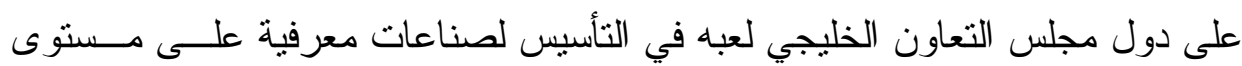
عالمي في المنطقة، لتتمكن من السير نحو مستقبل الاقتصـادات المعرفيــة و المنافـسة

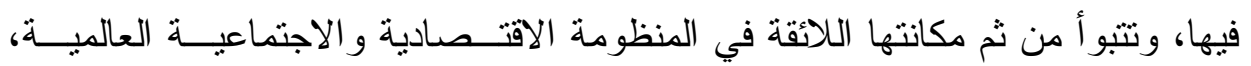
وبالاضافه أن انعقاد المؤتمر يأتي على خلفية من الحاجة إلى رسم خطة شاملة لــدول مجلس التعاون للإبقاء على القدرة التنافسية لصناعاتها في القرن الو احـــــ و العـشرين، وتتويع مصادر اقتصادها خارج نطاق قطاع النفط و الغاز .وينظم المــؤتمر بمـسـاهمة المؤسسة العربية للعلوم و التكنولوجيا، و المنظمة العربية للتتمية الــصناعية و التعـدين، وبرعاية قطر للبترول، و اسمارت غلوباله، و المجلس الأعلى للاتصالات وتكنولوجيا المعلومات، وقناة الجزيرة.وشارك في هذا الحــدث متحــدثون عــالميون بــارزون، و متخصصون في مجال الصناعات المعرفية وتقنية النانو من مؤسسات علمية مرموقة. وبيّن تقرير المنظمة تعدد واختلاف تطبيقات تقنية النانو حيث تشمل عمليـات إعـادة

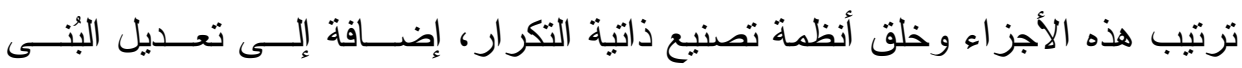

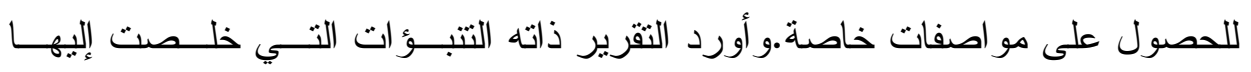

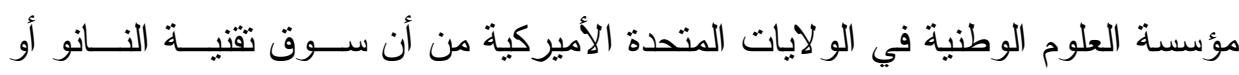
المنتجات التي تتفرع منها سيصل إلى تريليون دو لار خلال الفترة ما بين • 1 إلى 10

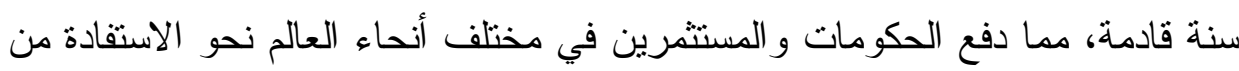

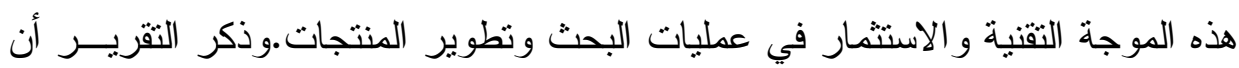
حجم الاستثمار في التطبيقات الصناعية المتعلقة بالتقنية الحيوية الصناعية يصل إلـى أكثر من • م مليار دو لار. 
توجه خولة قهلر نحو اقتهات المحرفة

وشدد د التقرير على ضرورة الاهتمام بالصناعات المعرفية لتطـــوير الرعايــة

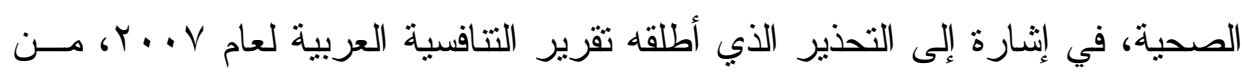
أن المنطقة ستو اجه ارتفاعا غير مسبوق في الطلب على الرعايــة الــصحية، إذ مــن

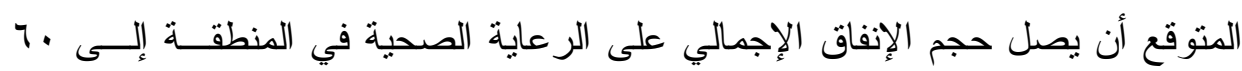

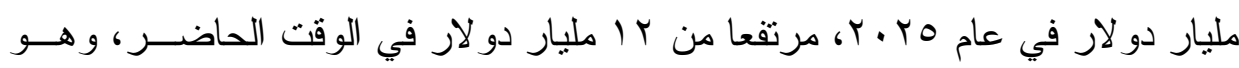

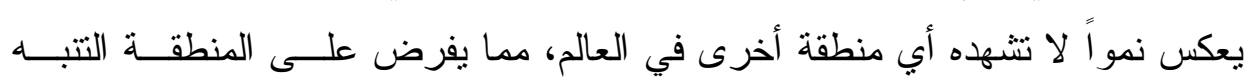

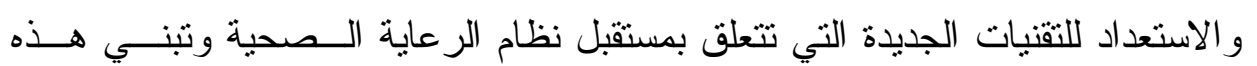
التقنيات بغرض السيطرة على تكاليف الرعاية الصحية في المنطقة مستقبلاً (ror) .

\section{أهداف مشروع التحول نحو الاقتصاد المعرفي :}

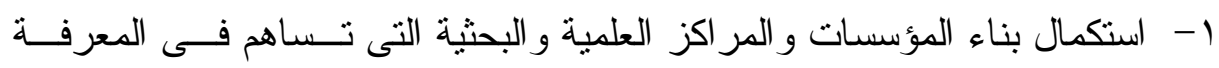

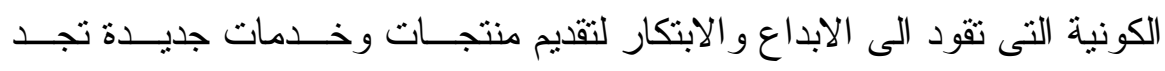
طريقها الى التنفيذ من خلال بيئة اقتصادية مناسبة. ץ- توفير فرص التعليم المتكافئة و التعلم المستمر للجميع وفرص العمل . r- توفير بنية تحتية ديناميكية للاتصالات و المعلومات توفر الخدمة بكفاءة . ع - خلق مجتمع يحافظ على قيمه ومعتقداته.

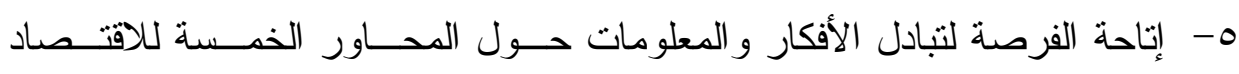

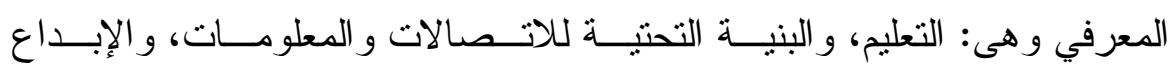
و الابتكار ، وبيئة الأعمال ،و المحور الاجتماعي. ولئ.

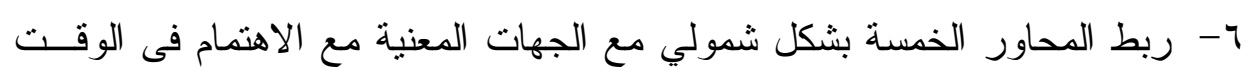
ذاته بتفعيل دور المجتمع.

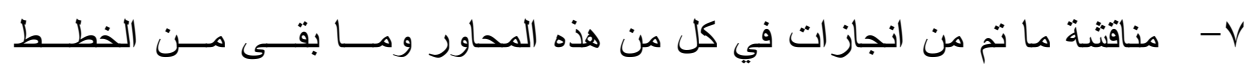

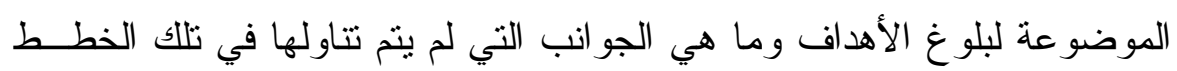
بهذف العمل و التخطيط لانجاز ها وفق أولويات متفق عليها 
خ. خالت الحلبى

ᄉ- وضع خطة عمل شمولية للاقتصـاد المعرفي لدولة قطر وتحديد هياكــل التتفيــذ و الجهات المناسبة لتنفيذها.

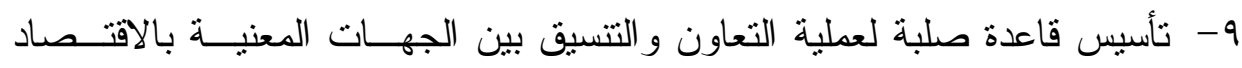
المعرفي وتفعيل دور المجتمع بشكل عام فى هذا المجال.

• - وبحث التوجهات المستقبلية لوضع خطة عمل تتفق عليها القطاعات المعنية بالاقتصاد المعرفي وتتبناها بشكل تكاملي ومنسق(بr) .

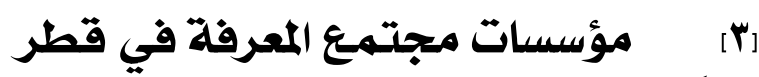

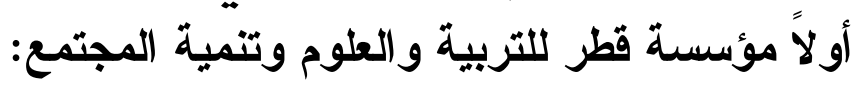

تنبت قطر في الخمس سنوات الأخيرة رؤية جديدة في التنمية الاقتصادية ترتكــز على فهم تداعيات التطور ات الاقتصادية في عصر العولمة وترتبط بتتفيذ اســتثمار ات ضخمة في مجال التعليم و العلوم والبحوث التطبيقية في إطار جعل اقتصاد المعرفة في دولة قطر نشطا وفاعلا ودوليا. فقد أسس الثيخ حمد بن خليفة آل ثاني أمير دولة قطر في في عام 1990 مؤسسة قطر للتربية و العلوم وتتمية المجتمع وهي منظمة خاصـــة غيـــر هادفة للربح وتر أس الثيخة موزة بنت ناصر المسسند حـرم الأميـر مجلـس ولس إدارة المؤسسة وتشرف شخصيا على أهدافها وبر امجها.

و تكمن رسالة مؤسسة قطر في تأهيل شعب دولة قطر ودول المنطقة علـى ونى

مو اجهة التحديات الناشئة في عالم دائم التغير و الارتقاء بدولة قطر إلى مصاف قياديــة

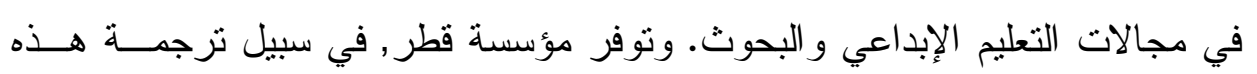

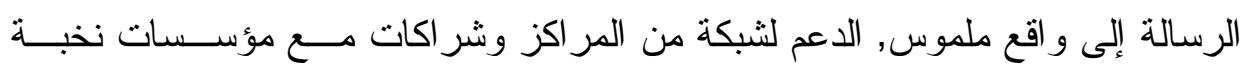

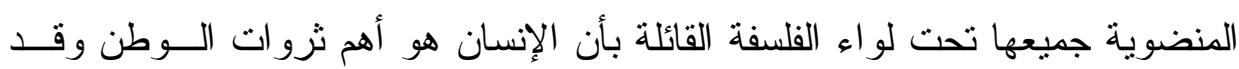

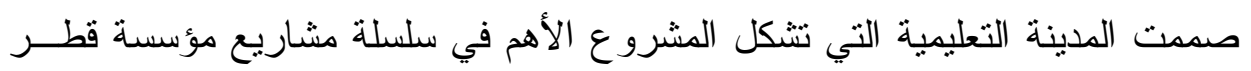

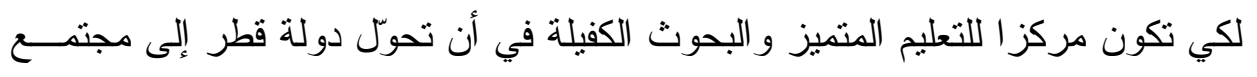
قائم على المعرفة. 
توجه خولة قهر نحو اقتهات المغرفة

ولتقييم هذه الرؤية يمكن التركيز في مجال هذا البحث علي مشروعين هامين

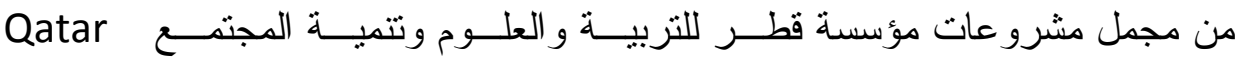
Science and Technology Oasis وهو و احة العلوم و التكنولوجيا Foundation و المدينة التعليمية.

\section{ا - مشروع واحة العلوم والتكنولوجيا Science and Technology Oasis}

جاء على لسان الدكتور أوليان روبــرتس المــدير التنفيــذي لواحــة العلــوم

$$
\text { و التكنولوجيا قوله : }
$$

"إن و احة العلوم و التكنولوجيا في قطر تقدّم مجموعة فريدة من الفوائد من حيث تمركزها في المدينة التعليمية في قطر • وتكمن مهمتتا في زيادة الفرص التـي يمكـن إتاحتها من خلال هذه الفو ائد وتوظيف خبر انتا الخاصة من أجل القيمة المضافة و التأكد من أن واحة العلوم و التكنولوجيا في قطر قد أصبحت من تلقاء نفسها محــوراً دوليــاً للأبحاث وشركات الأعمال المرتكزة على والتكنولوجيا". ويمكن الاتفاق مع هذا الرأي حيث توفر واحة قطر للعلوم و التكنولوجيا البيئــة التي تساعد على تطوير التكنولوجيات وتسويقها كما أنها تقدم مو اقع وخدمات بمعسايير

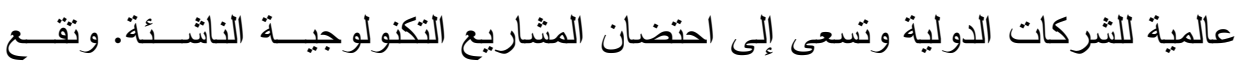

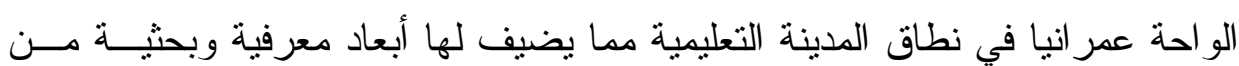
خلال علاقاتها الايجابية مع الجامعات البارزة. وتم إنـشـاء مـشروع و احسـة العلــوم و التكنولوجيا الذي يهدف الى بناء حاضنة للأعمال لتوفر من خلالها للشركات الناثــئة

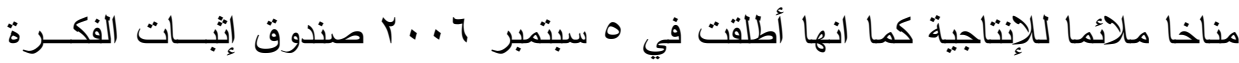
الذي يقام منحا للباحثين الذين يتخذون من دولة قطر مقر الهم . Proof of Concept وتدعيما للركيزة الاقتصادية للمشروع فقد تم طلاق صــندوقين للاســتثار ، صــندوق

الــشركات الناثـــئة New Enterprise Fund وصـــندوق الــشركات التقنيــة Technology Venture Fund المحللين فان هذا الحدث يمثل نقلة نوعية في الاقتصاد القطري ويجعل الدوحة احـدي

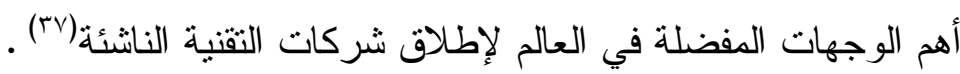


عينتت مؤسسة قطر للتربية و العلوم وتتمية المجتمع شركة ANGLE للتكنولوجيا،

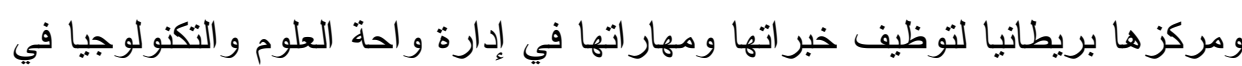

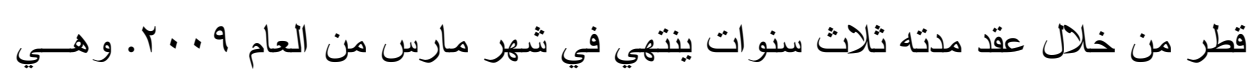

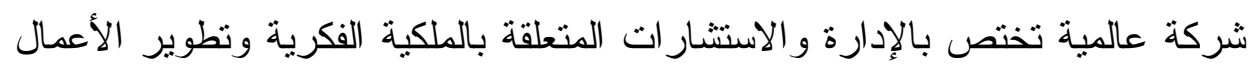
المرتكزة على التكنولوجيا. وتضطلع هذه الثركة بخبرة فريـــدة فـــي مجـــال العلـــوم

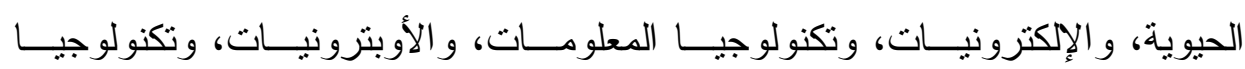
المصغر ات و البرمجة. ولذلك تمّ التعاقد مع شركة ANGLE للتكنولوجيا من أجل زيادة الفرص المتاحة للتطور أمام واحة العلوم و التكنولوجيا في قطر .

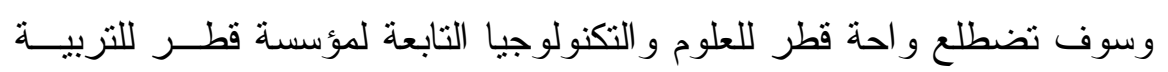

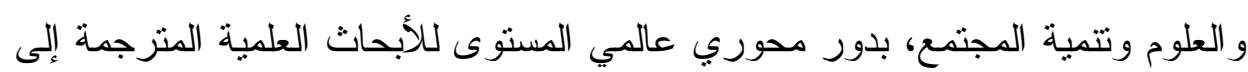

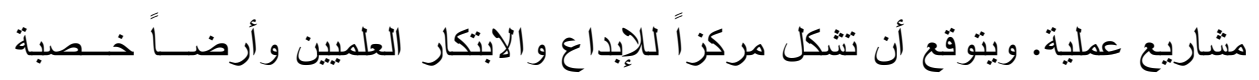

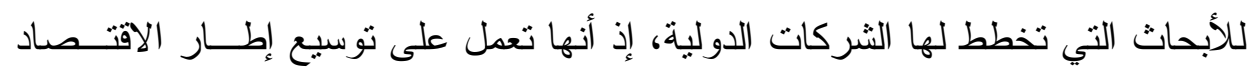
المحلي كما توفر فرصاً لا متتاهية للارتقاء في مجال الإبداع، وتوفر الدعم للمؤسسات

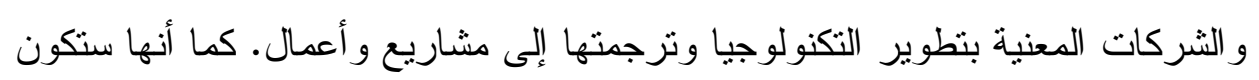

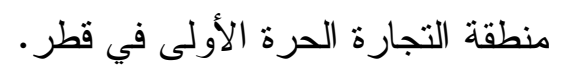

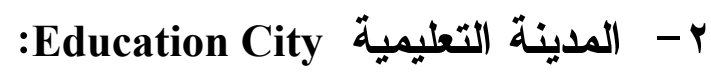
تعتبر المدينة التعليمية اهم المشاريع التي تتجزها مؤسسة قطر حيث انها تشغل مساحة

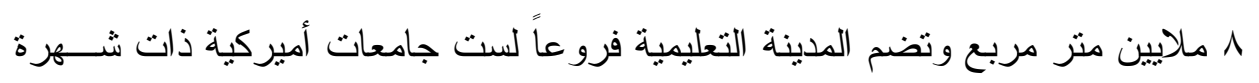
عالمية، هي : تضم المدينة التعليمية فروعاً لست جامعات أميركية ذات شهرة عالمية، هي : • جامعة فرجينيا كومنولث في قطر (1991)

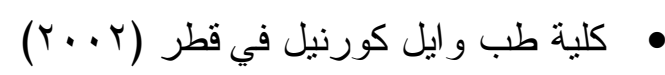

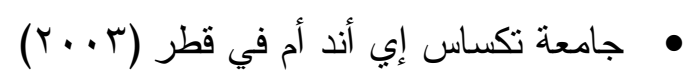

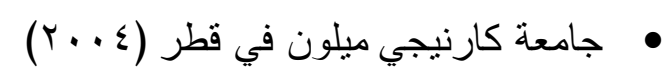
جامعة جورجتاون - كلية الثؤون الدولية في قطر (0 . . ب) 
توجه خولة قهر نحو اقتهات المحرفة

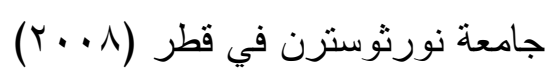

وقد صمّمت المدينة التعليمية بحيث تضم أيضا عددا و افــر ا مــن المـسـاكن و التسهيلات التزفيهية لكي تشكل مجتمعا من المؤسسات بــضـع بر امجـــه الأكاديميــة

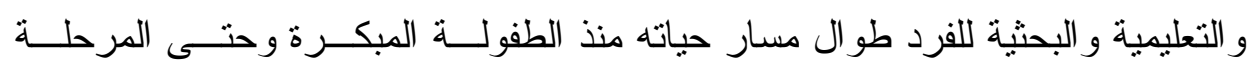
الجامعية المتقدمة.

\section{ثانياً شركة اتصالات قطر "كيوتل":}

شركة اتصالات قطر (كيوتل) هي شركة قطرية، مقرهـــا الدوحسـة، تأسـست

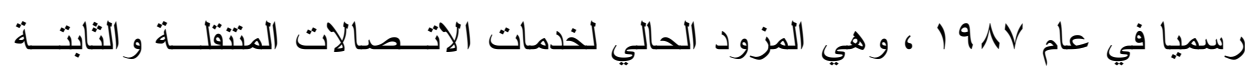

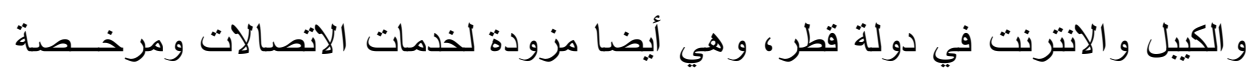
من قبل المجلس الأعلى لتكنولوجيا المعلومات والاتصالات في قطر لتوفير الاتصالات الثابتة و الجو الة في دولة قطر ، و يعمل في كيوتل أكثر من . . . V موظفا

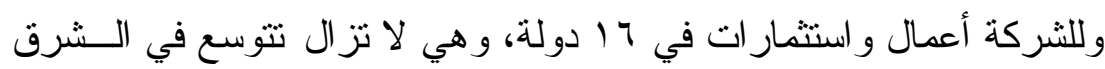
الأوسط وشمال أفريقيا وجنوب شرق آسيا، و الثركة تتمتع بأعلى ناتج محلي أجمــالي

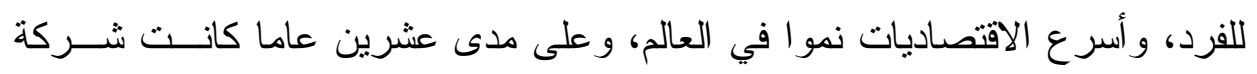

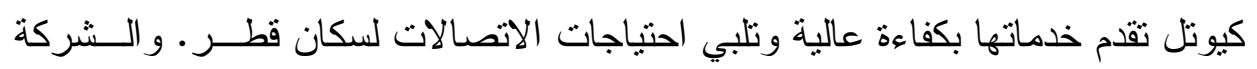

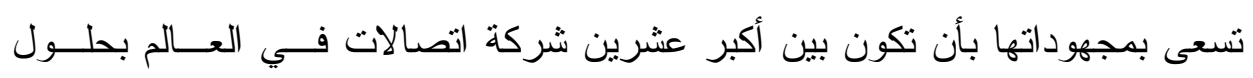
. Y. Y.

\section{• أهداف شركة كيوتل: مان}

وتتمثل هذه الأهداف فيما يلي:

1 - أن توفر لسكان قطر استخدام أسهل و أحدث منتجات وخدمات الاتصالات . r- مساعدة شعب قطر للارتقاء و التطور . r- أن تلعب دور ا بارزا في التطور الاجتماعي و الاقتصادي القطري. ع - تحسين خدمات الصحة و التعليم و الر عاية في قطر . ه- زيادة المعرفة بدولة قطر في العالم. 
7- الحد من تأثنير التقنيات التي تستخدمها كيونل على البيئة (†^). ثالثاً المجلس الأعلى للاتصالات: المجلس الأعلى للاتصالات هو الجهة المسئولة عن تكنولوجيا المعلومات والاتصالات

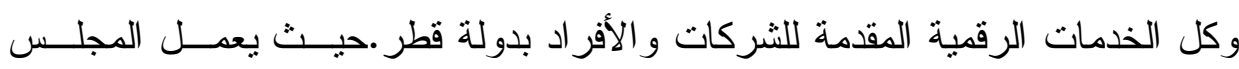

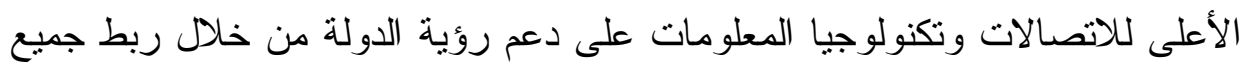

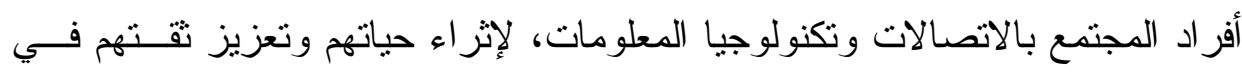

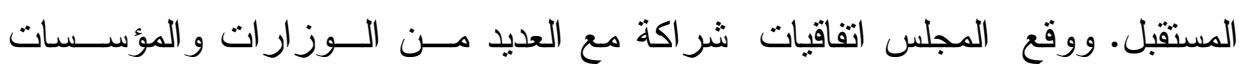

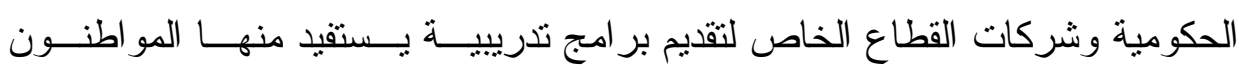
و المقيمون بدولة قطر • ويعمل المجلس على تطوير مهار ات الأفر اد سواء في إدخــال

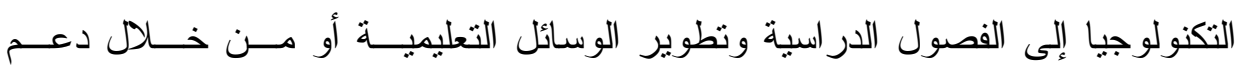
المهار ات المهنية للأفر اد، فالهدف الأبرز الذي يسعى المجلس إلى تحقيقه هو توصـيل الذيل كل أفر اد المجتمع بالتكنولوجيا لتصبح حياتهم أكثر سهولة وليصبحوا أكثر كفاءة وقدرة

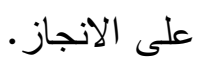

\section{النتائج والتوصيات:}

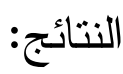

يستتتج مما سبق ما يلي:

1- أن هنالك خطو ات و اضحة سارت بها قطر نحو مجتمــع قـائم علــى الاقتــــاد

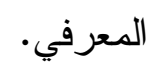

ץ- رغم التطور الذي حدث في وعي المجتمع القطري بأهمية التحول إلى الاقتـصاد

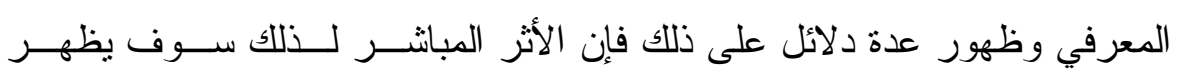

$$
\text { بصورة أوضح في السنوات القادمة. }
$$

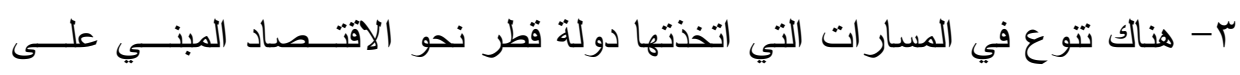
المعرفة، ويظهر ذلك من خلال التوجه نحو اتجاهات جديدة في التعلــيم، و إنــشاء مر اكز الأبحاث خاصة التكنولوجية منها، وتتجيع إنشاء الثركات و المـشرو عات الاستثمارية التي تعمل في مجال التكنولوجيا. 
توجه خولة قهر نحو اقتهاخ المعرفة

ع- فتح المجال أمام تمكين الثركات من امتلاك مكانة سوقية مرموقة وتحسين أدائها المالي وتفادي المنافسين و استثمار فرص جديدة.

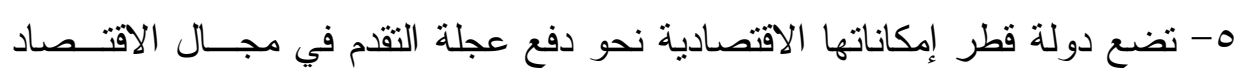
المبنى على المعرفة إضافة إلى سن التشريعات و القو انين التي تسهل ذلك التوجه التها

التوصيات

توصي الدر اسة بما يلي :

ا ـ وضع إجر اءات دقيقة تستهدف كل أرباب العمل لحملهم على استخدام التكنولوجيــا

الحديثة في مجال أعمالهم وبهذا يتوفر الوقت و الجهذ وبالتالي تزيد فرص الربح.

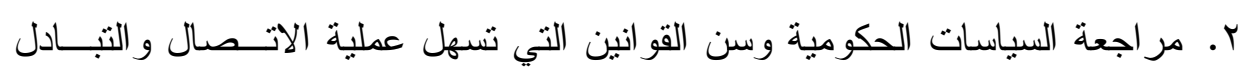

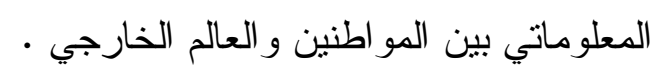

r. تشجيع أنشطة البحث و النطوير لتيسير قدرة الجميع على النفــاذ الــى تكنولوجيــا المعلومات و الاتصالات.

ـ. إنشاء مبادر ات حول الجامعات وشبكة التعليم هـ تحسين آليات صنع القرار في المجتمع العلمي وأهداف المجتمع محدّة بشكل جيد

من خلال الأخذ بآر اء المستخدمين النهائين التين

$$
\text { 7. نشر إمكانيات التعليم عن بُعد و إعادة الإدماج في المدرسة. }
$$

V. استخدام تقنيات صنع القرار، كتقييم التكنولوجيات وتحليل الإطار القراري، التـي

$$
\text { تُظهر تأثير ات القرار ات في الجمهور. }
$$

^. تشجيع الأطر اف السياسية والحكومات على أن تشرح بشكل أفضل في بر امجهــا

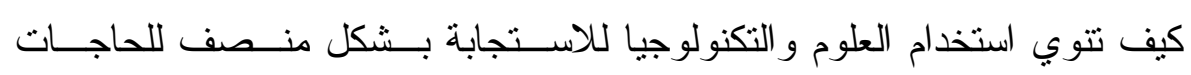
الاقتصادية الأساسية. 9. تشجيع وسائل الإعلام على رعاية برامج شعبية في العلوم خاصة من خلال إعداد الاد العاده

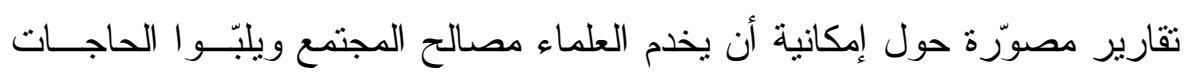
الأساسية للناس وحول تأثير ات العلوم في حياتهم وخاصة التأثير ات المختلفة للعلوم و التكنولوجيا في التطور الاقتصادي للمجتمع. 
خ· خالت الحلبى

• ا. ـ إثر الك المستخدمين النهائيين في تحديد الأولويات في مجال الأبحاث إضافة إلـى تصميم وتطبيق بر امج تكنولوجية وتتموية.

11 ا . على الحكومات أن تؤسّس مر اكز خبرات في العلوم و التكنولوجيا التي من شأنها إعطاء النصح للوز ار ات و غير ها من الهيئات الحكومي.

r ا. ت تأمين تعليم أساسي للجميع، خاصة تعليم المعارف العلمية و التكنولوجية الرئيسية،

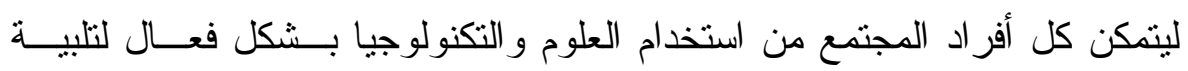

$$
\text { حاجاتهم الأساسية. }
$$

با. الاستفادة من الدول التي سبقتتا في هذا المجال و فهم آخر المستجدات في مجال إدارة المعرفة. - مارة

\section{مصادر الدراسة : مصنة:

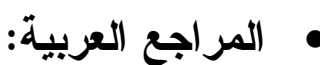

ا. اتحاد الخبر اءو الاستشاريون الدوليون. عائد الاستثمار في رأس المال البـشري،

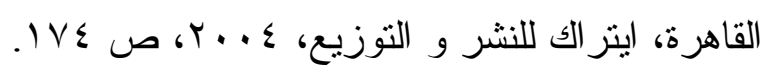

r. إدارة المعرفة - مفاهيم وملامح إدارية / محمود قطر ؛ في : الملتقى العربي العام

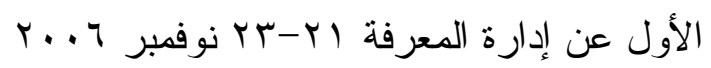

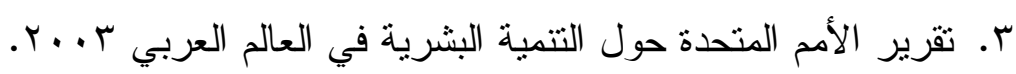

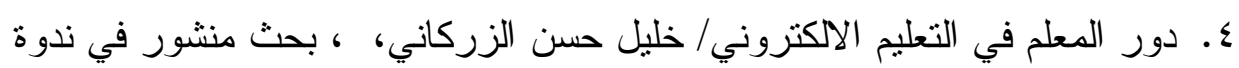

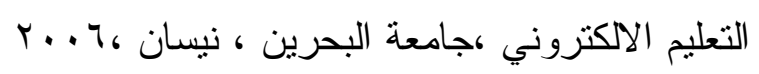

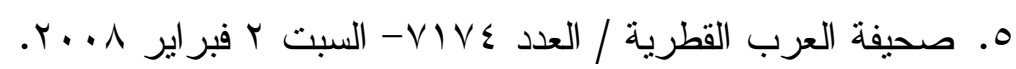

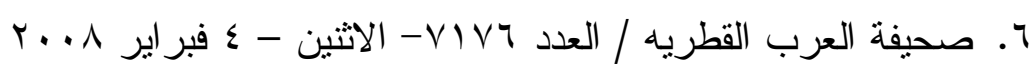

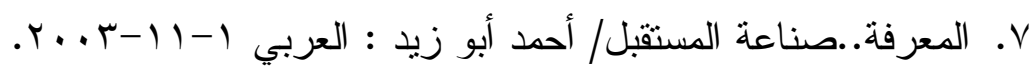

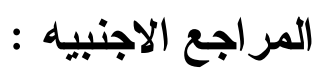

- Mashelkar, R., Economics of Knowledge, the th Dr. D.C. Deshmukh Memorial Lecture, 1999, New Delhi, India

\section{المراجع المنشورة عبر الآترنت :}




\section{توجه حولة قهر نحو اقتهات المخرفة}

$$
\text { ا ـ إدارة المعرفة / الدكتور سعد مرزوق العتيبى - منتديات اليسير متاح في }
$$

http://alyaseer.net/vb/showthread.php?t=6766:

$$
\text { r. اقتصاد المعرفة في مجتمع المعلومات / حسانه محيي الدين - متاح في }
$$

http://www.kfnl.gov.sa/idarat/KFNL_JOURNAL/M9-2/MagPages/7.htm

http://bahrainyourth.org/vb - r. اقتصاد المعرفه / العبيدلي

$$
\text { ع. اقتصاد المعرفه / عبدالرحمن الحاج : }
$$

http://www.css.kuniv.edu/vb/archive/index.php/t-723.html-

$$
\text { 0. الاقتصاد المعرفي / عبد الرحمن تبشوري- متاح في : }
$$

http://tdwl.net/vb/showthread.php?t=152454

7 . انطلاق ورشة العمل حول تحول دولة قطر نحو الاقتصاد المعرفي :

-http://www.bernama.com/arabic/news.php?id=16162

V. خليل حسن الزركاني. الاقتصاد المعرفي و التعليم الالكتروني ركيزتان في كفاءة

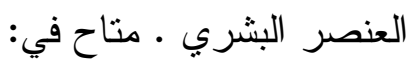

http://publications.ksu.edu.sa/Conferences/Knowledge\%20Cities\%20Confe rence $\% 20-\% 20$ Malaysia\%202007/Khalil\%20Zarkani.doc

^. روبرتس، اوليان ؛ موت ،ادوارد ـ أخبار الخليج ـ الملحق الاقتصادي ، العدد

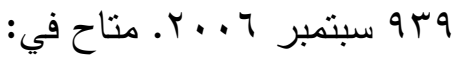

www.publications.ksu.edu.sa/Conferences/Merrakech\%20Conference/07.d

$$
\text { 9. }
$$

www.furat.alwehda.gov.sy/archive.asp?filename $=8600876622006103123$

: . المحد دياب دياب؛ في موقع البلاغ متاح في

http://www.balagh.com/islam/a10v58c0.htm 


$$
\text { 11ا. مقال عيسى مهنا بجريدة قاسيون ، متاح على موقع : }
$$

http://www.voltairenet.org/article135593.html

$$
\text { r ا ـالمنتدى العربي لادارة الموارد البشريه - }
$$

-http://www.hrdiscussion.com/hr2597.html:

www.ahewar.org/debat/show.art.asp?aid=50457 : بوقع الحوار

ـ ا.موقع الموسوعة الحرة ويكيبيديا-متاح في : http://ar.wikipedia.org/wik

ا اموقع قناة العربية ، من مقال آلفن توفلز بجريدة الاتحاد الإمار انية - متاح في :

http://www.alarabiya.net/views/2006/04/14/22839.html

$$
\text { 17 أوزارة التربيه والتعليم - الاردن - متاح في : - }
$$

www.moe.gov.jo/dera/dera1.pps

\section{الهوامش}

1- إدارة المعرفة -مفاهيم وملامح إدارية / محمود قطر ؛ في: الملتقى العربي العام

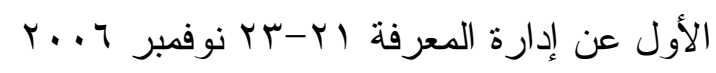

r- إدارة المعرفة / سعد مرزوق العتيبى - منتديات اليسير متاح في :

باريخ الاطلاع http://alyaseer.net/vb/showthread.php?t=6766

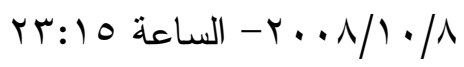

-http://bahrainyourth.org/vb - ب- اقتصاد المعرفه / العبيدلي

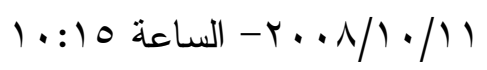

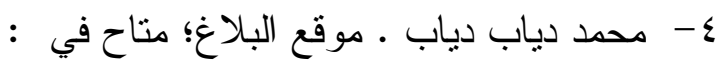

http://www.balagh.com/islam/a10v58c0.htm

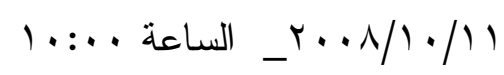

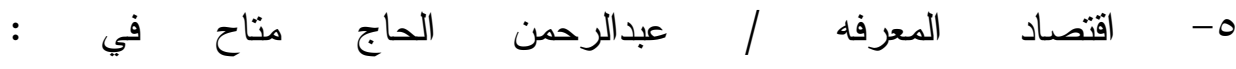

6 $\quad$ http://www.css.kuniv.edu/vb/archive/index.php/t-723.html-

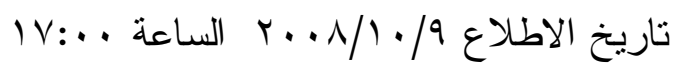


توجه حولة قهر نحو اقتهاخ المحرفة

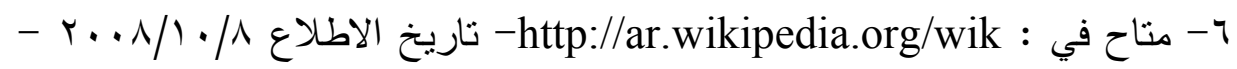

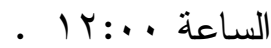

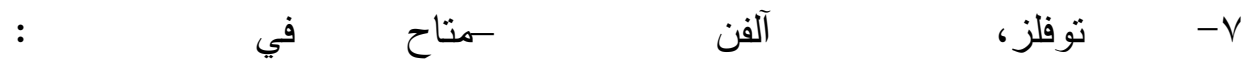

http://www.alarabiya.net/views/2006/04/14/22839.html

$$
\text { 17:1 } 1 \text { \& }
$$

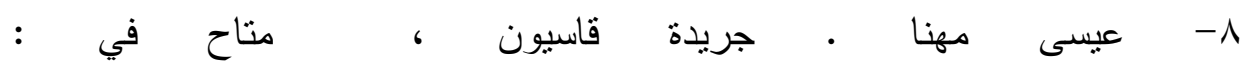

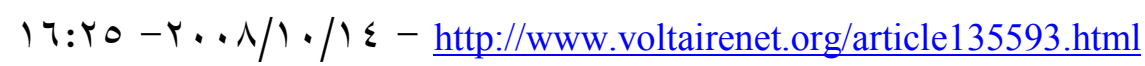

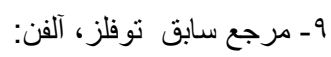

http://www.alarabiya.net/views/2006/04/14/22839.html

• ا- الاقتصاد المعرفي و التعليم الالكتروني ركيزتان في كفاءة العنصر البشري/ خليل

حسن الزركاني - جامعة بغداد

11

WWW.moe.gov.jo/dera/dera1.pps

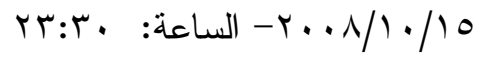

$$
\begin{aligned}
& \text { r ا - وزارة التربيه و التعليم - الاردن - المرجع السابق }
\end{aligned}
$$

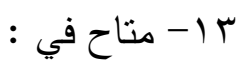

$\underline{\text { www.furat.alwehda.gov.sy } / \text { archive.asp?filename }=86008766220061031235230}$

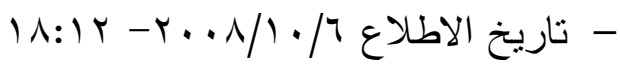

$$
\begin{aligned}
& \text { ع ا- نفس المرجع : }
\end{aligned}
$$

$\underline{\text { www.furat.alwehda.gov.sy } / \text { archive.asp?filename }=86008766220061031235230}$

$$
10
$$

17

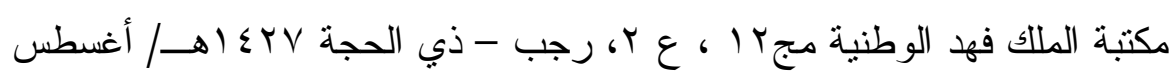
r. . T 
YV V V - كريم ابو حلاوة، اين العرب من مجتمع المعرفة. مرجع سابق صابع http://www.mokarabat.com/mo10-21.htm

11- محسن خضر، مجتمع المعرفة العربي : عوائقه وآماله ص htt:www.afkaronline.org/Arabic/archives 1 tuibll-out 2004/khedher.html r

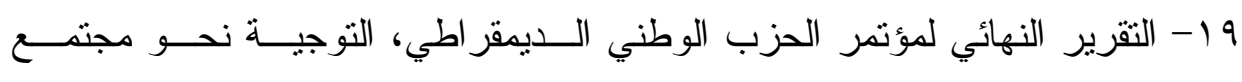

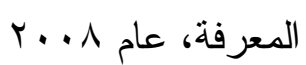

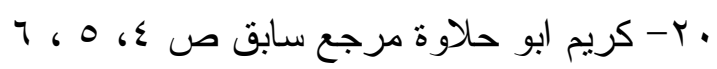
http://Www.writers.alriradh.com $-r)$

$\mathrm{Sa} /$ kpage.(18.2.2009)

r r- ميتشو كاكو، رؤية مستقبلية . كيف سيغير العلم حياتتا في القرن الواحد و العشرين، ترجمة د. سعد الدين خرفان، مر اجعة محمد يونس، سلسلة المعرفة ،

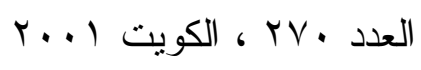

Alvin.To ffler: Future shook, New York, $8^{\text {th }}$ ed.Bantam Book, rr 2004,p 26

ـ ץ- عبد الله نركمان، مجتمع المعرفة : و ابعاده في المجتمع العربي (مرجع سابق) 2/s/42.htmhttp://hem.bredband:net/clccls ص r r ه - مرجع سابق - وزارة التربيه والتعليم .الاردن : www.moe.gov.jo/dera/dera1.pps

بr- الاقتصاد المعرفي / / عبد الرحمن تيشوري- مناح في :

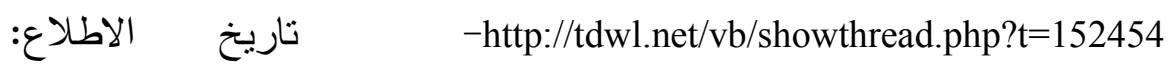

$$
\text { I r r...1/1./1. }
$$

V V- اتحاد الخبر اءو الاستشاريون الدوليون، عائد الاستثمار في رأس المال البشري،

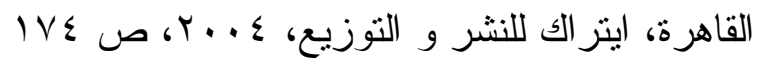


توجه خولة قهر نحو اقتهات المعرفة

$$
\begin{aligned}
& \text { ^ץ- - المنتدى العربي لادارة الموارد البشريه - متاح في : } \\
& \text {-http://www.hrdiscussion.com/hr2597.html }
\end{aligned}
$$

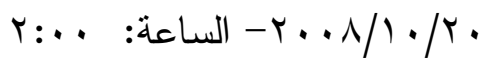

$$
\begin{aligned}
& \text { وץ- دور المعلم في التعليم الاكتروني/ خليل حسن الزركاني؛ في: ندوة التعليم }
\end{aligned}
$$

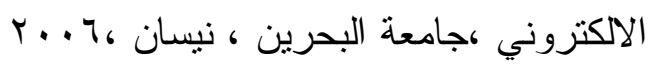

• ب- موقع الحوار :

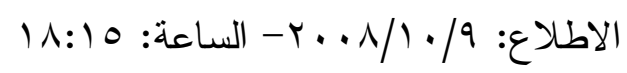

اب- حسانه محيي الدين. اقتصاد المعرفة في مجتمع المعلومات - متاح في المعات

http://www.kfnl.gov.sa/idarat/KFNL_JOURNAL/M9-2/MagPages/7.htm

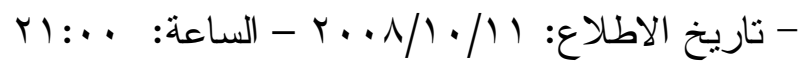

$$
\begin{aligned}
& \text { rr- حسانه محيي الدين. المرجع السابق }
\end{aligned}
$$

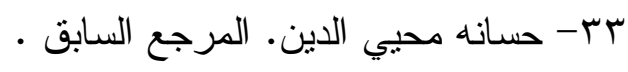

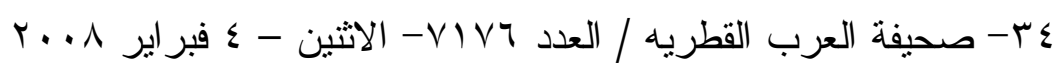

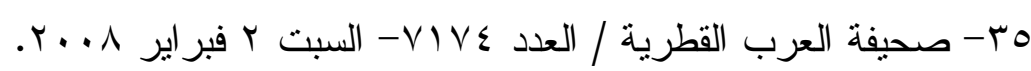

بrttp://www.bernama.com/arabic/news.php?id=16162

$$
r \cdot . . . .1 / 1 \cdot / 10
$$

Vr- روبرتس، اوليان ؛ موت ،ادوارد ـ أخبار الخليج • الملحق الاقتصادي ، العدد

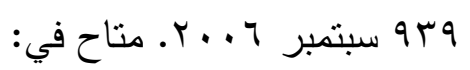

www.publications.ksu.edu.sa/Conferences/Merrakech\%20Conference/07.doc

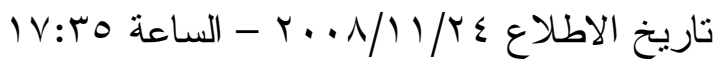

$$
\begin{aligned}
& \text { مب- موقع شركة كيوتل Www.qtel.com.qa }
\end{aligned}
$$

